\title{
Instrument Qualification of Custom Fabricated Water Activity Meter for Hot Cell Use
}

J. K. McCoskey

Washington River Protection Solutions LLC

Date Published

January 2014

Prepared for the U.S. Department of Energy

Assistant Secretary for Environmental Managment

P.O. Box 850

Richland, Washington

Contractor for the U.S. Department of Energy

Office of River Protection under Contract DE-AC27-08RV14800 
LAB-RPT-13-00006

Rev. 0

TRADEMARK DISCLAIMER

Reference herein to any specific commercial product, process,

or service by trade name, trademark, manufacturer, or

otherwise, does not necessarily constitute or imply its

endorsement, recommendation, or favoring by the United

States Government or any agency thereof or its contractors or subcontractors.

This report has been reproduced from the best available copy.

Printed in the United States of America 


\section{Contents}

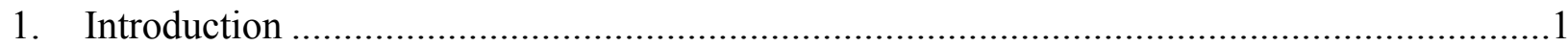

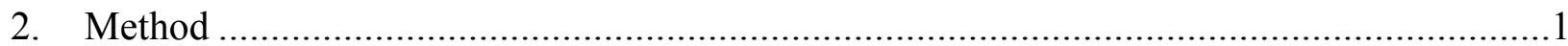

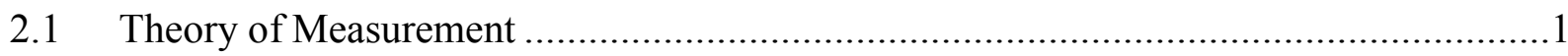

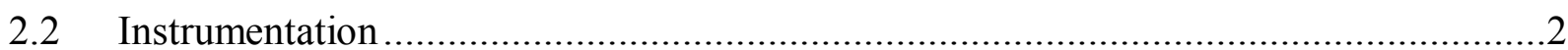

2.3 Water Activity Measurement Using Humidity Sensor Only (Method 1) .........................4

2.4 Water Activity Measurement Using Humidity Sensor and Temperature Sensor

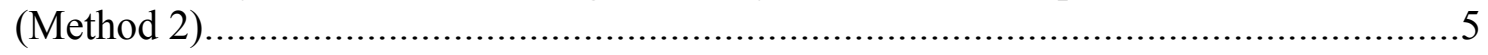

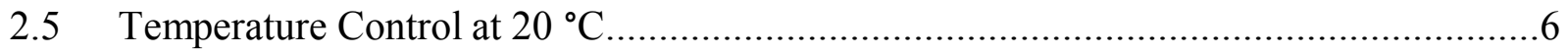

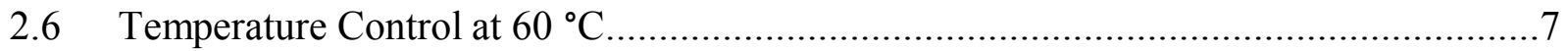

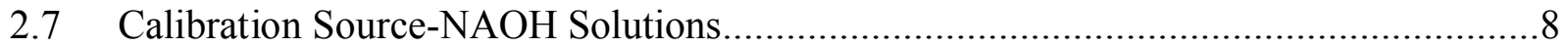

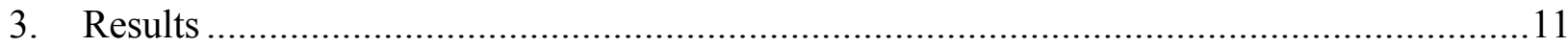

$3.1220^{\circ} \mathrm{C}$ Results Using Humidity Sensor Only ...........................................................11

$3.220^{\circ} \mathrm{C}$ Results Using Humidity Sensor and Temperature Sensor...................................12

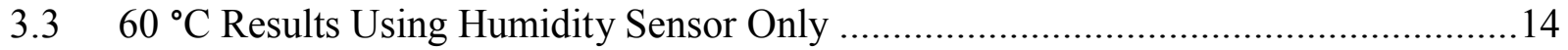

$3.4 \quad 60^{\circ} \mathrm{C}$ Results Using Humidity Sensor and Temperature Sensor...................................16

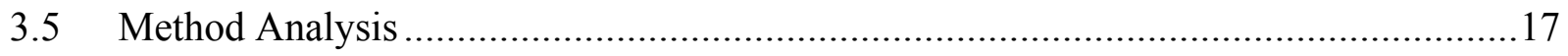

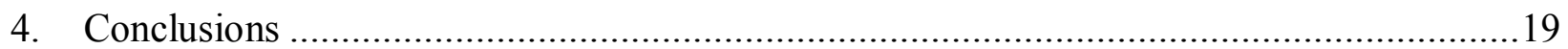

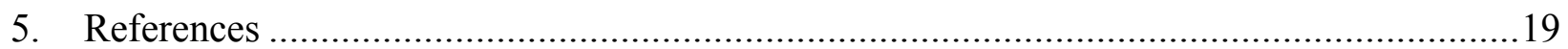

Appendix A Linear Regressions Engineering Calculation.................................................... A-i

\section{List of Figures}

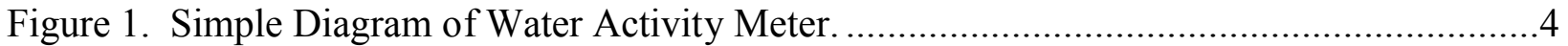

Figure 2. Water Activity Data for Aqueous $\mathrm{NaOH}$ Solutions................................................. 9

Figure 3. Measured and Literature Values or Water Activity of $20^{\circ} \mathrm{C} \mathrm{NaOH}$ Solutions at Varying Concentrations Using a Humidity Probe Only..........................................12

Figure 4. Measured and Literature Values or Water Activity of $20^{\circ} \mathrm{C} \mathrm{NaOH}$ Solutions at Varying Concentrations Using a Humidity Probe and Temperature Probe. .................14

Figure 5. Measured and Literature Values or Water Activity of $60{ }^{\circ} \mathrm{C} \mathrm{NaOH}$ Solutions at Varying Concentrations Using a Humidity Probe Only...........................................15

Figure 6. Measured and Literature Values or Water Activity of $60{ }^{\circ} \mathrm{C} \mathrm{NaOH}$ Solutions at Varying Concentrations Using a Humidity Probe and Temperature Probe. 


\section{List of Tables}

Table 1. Average Temperature and $3 \sigma$ Standard Deviation for $20^{\circ} \mathrm{C}$ Experiments. (2 sheets) ....6

Table 2. Average Temperature and $3 \sigma$ Standard Deviation for $60^{\circ} \mathrm{C}$ Experiments. (2 sheets) ....7

Table 3. $\mathrm{NaOH}$ Solution Concentrations and Estimated Water Activity. .................................8

Table 4. Water Activity Constants for Sigmoid Regression Equation.................................10

Table 5. NaOH Solutions Used for Each Experiment.................................................... 10

Table 6. Tabulated Water Activity of $\mathrm{NaOH}$ Solutions Using Only a Humidity Probe at a Temperature of $20^{\circ} \mathrm{C}$.

Table 7. Tabulated Water Activity of $\mathrm{NaOH}$ Solutions Using Humidity Probe in Conjunction with a Temperature Probe at a Temperature of $20{ }^{\circ} \mathrm{C}$.

Table 8. Tabulated Water Activity of $\mathrm{NaOH}$ Solutions Using Only a Humidity Probe at a Temperature of $60^{\circ} \mathrm{C}$.

Table 9. Tabulated Water Activity of $\mathrm{NaOH}$ Solutions Using a Humidity Probe and

Temperature Probe at a Temperature of $60^{\circ} \mathrm{C}$. 16

Table 10. Consolidated Results of $20^{\circ} \mathrm{C}$ Water Activity Experiments. 18

Table 11. Consolidated Results of $60^{\circ} \mathrm{C}$ Water Activity Experiments. 18

\section{List of Equations}

Equation 1. Chemical Potential as a Function of Fugacity. .............................................

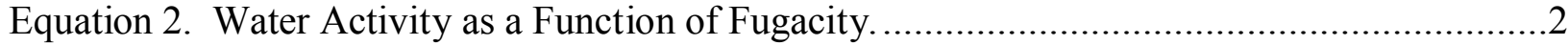

Equation 3. Estimated Water Activity as a Function of Pressure ........................................2

Equation 4. Equilibrium Relative Humidity.......................................................................2

Equation 5. Water Activity as a Function of Equilibrium Relative Humidity. ..........................5

Equation 6. Water Vapor of Head Space as a Function of Relative Humidity. ..........................5

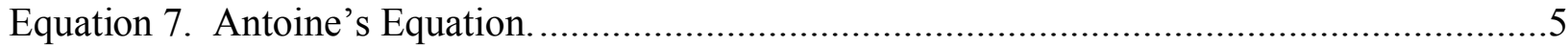

Equation 8. Estimated Water Activity as a Function of Vapor Pressure. ..................................6

Equation 9. Sigmoid Regression Equation..................................................................... 


\section{LAB-RPT-13-00006 Rev. 0}

\section{List of Terms}

\section{Acronyms and Abbreviations}

$\begin{array}{ll}\text { ATL } & \text { Advanced Technologies and Laboratories International, Inc. } \\ \mathrm{a}_{\mathrm{w}} & \text { Water Activity } \\ a_{w} & \text { Water Activity } \\ \mathrm{NaOH} & \text { Sodium Hydroxide } \\ \mathrm{PMP} & \text { Polymethylpentene } \\ \mathrm{R}^{2} & \text { Coefficient of Determination } \\ \mathrm{RH} & \text { Relative Humidity } \\ \text { RPD } & \text { Reported Percent Difference }\end{array}$

\section{Units}

$\begin{array}{ll}\sigma & 1 \text { standard deviation } \\ \% & \text { percent } \\ \mathrm{bar} & \text { unit of pressure } \\ { }^{\circ} \mathrm{C} & \text { degrees Celsius } \\ \mathrm{g} & \text { gram } \\ \mathrm{kg} & \text { kilogram } \\ \mathrm{mL} & \text { milliliter } \\ \text { Mohm } & 10^{6} \mathrm{Ohms} \\ \text { molal } & \text { moles } / \mathrm{kg} \mathrm{H}_{2} \mathrm{O} \\ \text { mole } & 6.02 \times 10^{23} \text { objects }\end{array}$




\section{INTRODUCTION}

A custom fabricated water activity meter was developed to determine the water activity of electrolyte solutions. More importantly, the meter was developed for use in a hot cell to determine the water activity of supernatant liquids. Water activity is a measure of the intensity with which water associates with non-aqueous molecules in the system. For this reason, the water activity is an important variable in predicting the partitioning of hydrated solid phases during normal Hanford processes such as mixing tank waste types, caustic additions, evaporator campaigns, tank transfers and retrievals, and staging of waste for transfer to the Waste Treatment and Immobilization Plant.

This report describes a custom fabricated water activity meter and the results of the qualification of this meter as described in the laboratory test plan LAB-PLN-11-00012, Testing and Validation of an Enhanced Acquisition and Control System. It was calibrated against several $\mathrm{NaOH}$ solutions of varying concentrations to quantify the accuracy and precision of the instrument at $20^{\circ} \mathrm{C}$ and $60{ }^{\circ} \mathrm{C}$. Also, a schematic and parts list of the equipment used to make the water activity meter will be presented in this report.

\section{METHOD}

\subsection{THEORY OF MEASUREMENT}

Water activity can be derived from basic thermodynamic and physical principles. The chemical potential of a substance can be described by Equation 1. Some requirements must be met for this thermodynamic principle. First, pure water is the standard state where the water activity $\left(a_{\mathrm{w}}\right)$ is equal to $1\left(a_{w}=1\right)$. Second, the system must be at equilibrium at a defined temperature.

\section{Equation 1. Chemical Potential as a Function of Fugacity.}

$$
\mu=\mu_{o}+R \operatorname{Tln}\left(f / f_{0}\right)
$$

Where:

$\mu=$ chemical potential of substance (water)

$\mu_{o}=$ chemical potential of substance at standard state

$R=$ gas constant

$T=$ temperature of the system at equilibrium

$\mathrm{f}=$ fugacity of substance

$\mathrm{f}_{\mathrm{o}}=$ fugacity of substance at standard state. 
The activity of a substance is defined as $a=f / f_{o}$. In the case of water, the water activity will be denoted as shown in Equation 2, where $w$ is the notation for water.

\section{Equation 2. Water Activity as a Function of Fugacity.}

Where:

$$
a_{w}=\frac{f}{f_{o}}
$$

$$
a_{w}=\text { activity of water. }
$$

Fugacity is a metric of the non-ideal deviation of the chemical potential for a real gas from that of an ideal gas. For condensed phases of liquid at near standard pressures ( 1 bar), the real vapor pressure has nearly the same chemical potential as the vapor pressure of an ideal liquid. Therefore, the fugacity terms in Equation 2 can be estimated and replaced by partial pressure term, as seen in Equation 3.

\section{Equation 3. Estimated Water Activity as a Function of Pressure.}

Where:

$$
a_{\mathrm{w}}=\frac{P_{\mathrm{H}_{2} \mathrm{O}}}{P_{\mathrm{H}_{2} \mathrm{O}}^{*}}
$$

$$
\begin{aligned}
& P_{\mathrm{H}_{2} \mathrm{O}}=\text { Water Vapor Partial Pressure } \\
& P_{\mathrm{H}_{2} \mathrm{O}}^{*}=\text { Water Vapor Saturated Partial Pressure. }
\end{aligned}
$$

The water activity can also be described in terms of equilibrium relative humidity as displayed in Equation 4. The equilibrium relative humidity can be described as the relative humidity of the head space when the solution and head space gasses are in thermodynamic equilibrium.

\section{Equation 4. Equilibrium Relative Humidity.}

$$
E R H=100 \%\left(\frac{P_{\mathrm{H}_{2} \mathrm{O}}}{P_{\mathrm{H}_{2} \mathrm{O}}^{*}}\right)=100 \%\left(a_{w}\right)
$$

Where:

$$
E R H=\text { Equilibrium Relative Humidity } .
$$

\subsection{INSTRUMENTATION}

The humidity meter is a $125 \mathrm{~mL}$ polymethylpentene (PMP) jar (Nalgene, 2117-0125) with a humidity sensor and temperature probe mounted to the lid of the jar by airtight fittings. Figure 1 
is a simple diagram of the water activity meter. During operation, the humidity sensor was in contact with the vapors and gasses in the head space and was used to measure the water concentration and temperature of the head space contents. The temperature probe was in contact with the solution in the jar and was used to measure the temperature of the solution in the vessel. The contents in the jar are sealed from the ambient atmosphere, and because the system is sealed, the water vapor in the head space was in equilibrium with the solution in the vessel at a temperature.

The water activity sensors included a Vaisala humidity sensor (Vaisala, HMP110) and a temperature probe (LabJack, EI1034 Temperature Probe). The humidity sensor is a capacitancestyle sensor with a stated accuracy of $\pm 1.7 \%$ from $0-90 \%$ relative humidity $(\mathrm{RH})$ and $\pm 2.5 \%$ from $90-100 \% \mathrm{RH}$. The humidity sensor was equipped with a temperature sensor with a stated accuracy of $\pm 0.2{ }^{\circ} \mathrm{C}$ from 0 to $+40{ }^{\circ} \mathrm{C}$ and $\pm 0.4{ }^{\circ} \mathrm{C}$ from -40 to $0{ }^{\circ} \mathrm{C}$ and +40 to $80{ }^{\circ} \mathrm{C}$. The LabJack temperature probe incorporates a LM34CAZ silicon-type sensor from National Semiconductor mounted inside a stainless steel tube. The stated accuracy of the temperature probe is $\pm 1.1^{\circ} \mathrm{C}$ from 0 to $110^{\circ} \mathrm{C}$ and $\pm 1.7^{\circ} \mathrm{C}$ from -40 to $0^{\circ} \mathrm{C}$. Both the humidity sensor and temperature probe were inserted through the lid of the PMP jar. The humidity sensor was sealed from the outside atmosphere using the supplied mounting flange from Vaisala. The temperature probe was sealed from the outside environment using a 1/4-inch panel mount, bore through, compression fitting manufactured by Cole Parmer (Part \# EW-06390-10).

The humidity probe and temperature probe were connected to a LabJack U3-HV data acquisition device, which was operated through DAQFactory process control software made by Azeotech. The data acquisition device provided operating voltages to the measurement probes and also provided voltage detection of the probes. The software was used to provide a user interface and convert the output voltages from the measurement probes to usable data. 


\section{Figure 1. Simple Diagram of Water Activity Meter.}

To DAQ device

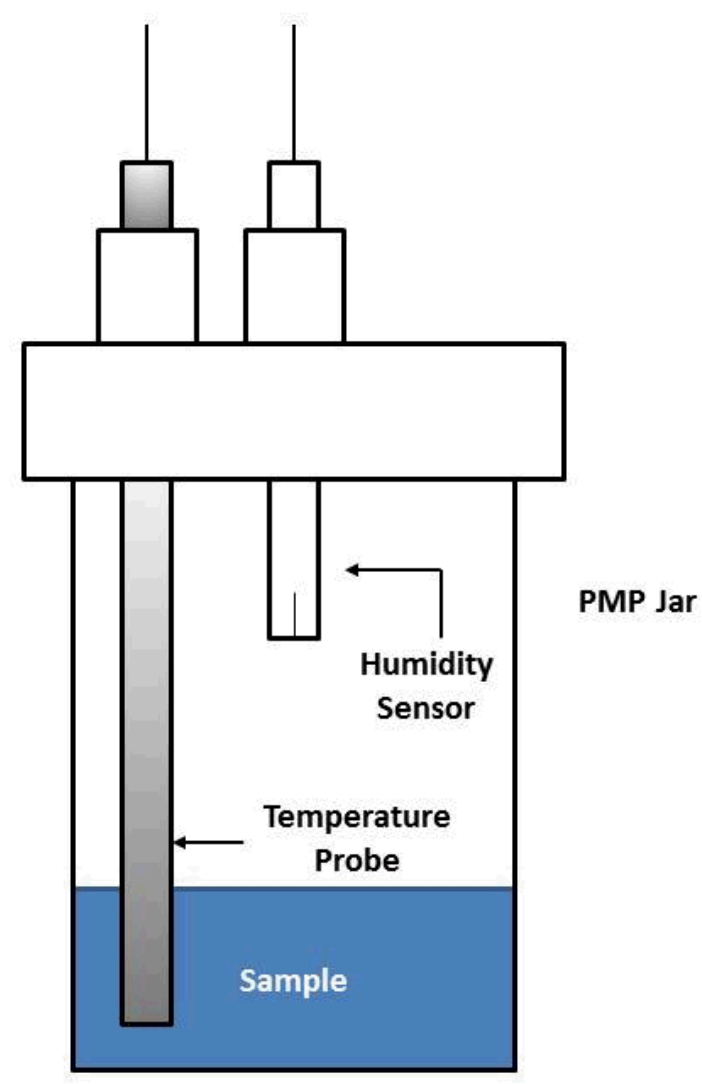

The water activity of the solution can be determined either directly from the humidity sensor alone or from both the humidity sensor and the temperature probe. Both applications will be explained in the following section along with the advantages and disadvantages of each measurement technique.

\subsection{WATER ACTIVITY MEASUREMENT USING HUMIDITY SENSOR ONLY (METHOD 1)}

The water activity can be determined with knowledge of the water vapor content and temperature of the headspace, assuming the gases and vapors in the head space are in thermodynamic equilibrium with the electrolyte solution. These two variables can be determined using the humidity probe only. This method has several advantages. These include the use of a single sensor that does not come into contact with the sample, and that no error is introduced during the conversion of the sensor output data to water activity data. Equation 5 is the only required conversion. 
Equation 5. Water Activity as a Function of Equilibrium Relative Humidity.

$$
a_{w}=\frac{E R H}{100 \%}
$$

Where:

$a_{w}=$ water activity

$E R H=$ Equilibrium Relative Humidity.

\subsection{WATER ACTIVITY MEASUREMENT USING HUMIDITY SENSOR AND TEMPERATURE SENSOR (METHOD 2)}

The water activity can also be determined using the measured humidity and temperature of the vapor and gases in the head space and the measured temperature of the solution. The humidity and temperature of the head space are determined using the humidity probe; applying these data to Equation 6, the partial pressure of water in the head space can then be determined. The saturated water vapor pressure $\left(P_{\mathrm{H}_{2} \mathrm{O}}^{*}\right)$ is estimated from the measured solution temperature as determined from the humidity probe using Antoine's Equation (Equation 7). Knowing the value of these variables, the water activity can be determined though Equation 8 .

Equation 6. Water Vapor of Head Space as a Function of Relative Humidity.

Where:

$$
P_{\mathrm{H}_{2} \mathrm{O}}(\text { Vapor })=P_{\mathrm{H}_{2} \mathrm{O}}^{*}(\text { Vapor })\left(\frac{R H}{100 \%}\right)
$$

$R H=$ Relative Humidity

$P_{\mathrm{H}_{2} \mathrm{O}}^{*}($ Vapor $)=$ Saturated Water Vapor in the Head Space.

\section{Equation 7. Antoine's Equation.}

$$
\log _{10} P_{H_{2} O}^{*}=A-\frac{B}{T+C}
$$

Where:

$T=$ Vapor Space or Solution Temperature as Appropriate in Kelvin

$A=8.10765$ (For Water from $0-60^{\circ} \mathrm{C}$ )

$B=1750.286\left(\right.$ For Water from $0-60^{\circ} \mathrm{C}$ )

$C=235.000$ (For Water from $0-60^{\circ} \mathrm{C}$ ). 


\section{Equation 8. Estimated Water Activity as a Function of Vapor Pressure.}

$$
a_{w}=\frac{P_{H_{2} \mathrm{o}}(\text { Vapor })}{P_{H_{2} \mathrm{o}}^{*}(\text { Solution })}
$$

Where:

$$
\begin{aligned}
P_{\mathrm{H}_{2} \mathrm{O}}^{*}(\text { Solution })= & \text { Saturated Vapor Pressure as determined through } \\
& \text { Antoine's Equation. }
\end{aligned}
$$

The just-described method is much more robust than determining the water activity using the humidity probe only. For measurements made with the humidity probe alone, only the water vapor in the head space is measured, and care must be taken to ensure the solution is at the same temperature as the head space for an accurate measurement. This was not always the case in these experiments due to environmental and equipment factors. With the system that incorporates the solution temperature, the solution and head space do not have to be at the same temperature, and the saturated vapor pressure of the solution can be instantaneously determined along with the partial pressure of the water vapor in the head space.

\subsection{TEMPERATURE CONTROL AT $20^{\circ} \mathrm{C}$}

For the experiments conducted at $20^{\circ} \mathrm{C}$, the solutions were cooled using a Peltier cooled dry bath (Torrey Pines Scientific, EchoTherm ${ }^{\mathrm{TM}^{1}}$ IC35) in conjunction with a custom-manufactured aluminum block surrounded with a greenhouse. The aluminum block was milled to fit the water activity meter pictured above in Figure 1, and all but the lid and top sides of the sensors rested inside the aluminum block. The greenhouse surrounded the water activity meter components not directly inside the aluminum block. The greenhouse was constructed of $1 / 2$-inch thick polyamide insulation walls to thermally isolate the water activity meter and aluminum block from the ambient atmosphere. The dry bath was in contact with the bottom of the aluminum block. To cool the solution in the water activity meter, the dry bath was set to $19^{\circ} \mathrm{C}\left(1{ }^{\circ} \mathrm{C}\right.$ Resolution), and the resulting solution temperature stabilized to around $19.6{ }^{\circ} \mathrm{C}$. Table 1 shows the average solution temperature and vapor space temperature of the experiments conducted using this system.

Table 1. Average Temperature and $3 \sigma$ Standard Deviation for $20^{\circ} \mathrm{C}$ Experiments. ( 2 sheets)

\begin{tabular}{lcccc}
\hline Experiment & $\begin{array}{c}\text { Average Head } \\
\text { Space } \\
\text { Temperature }\left({ }^{\circ} \mathbf{C}\right)\end{array}$ & $\begin{array}{c}\text { Head Space } \\
\text { Temperature } \\
\text { Standard Deviation } \\
(\mathbf{3 \sigma})\end{array}$ & $\begin{array}{c}\text { Average Solution } \\
\text { Temperature }\left({ }^{\circ} \mathbf{C}\right)\end{array}$ & $\begin{array}{c}\text { Solution Temperature } \\
\text { Standard Deviation } \\
(\mathbf{3 \sigma})\end{array}$ \\
\hline 2.5 Molal & 21.1 & 0.182 & 20.0 & 0.042 \\
5.0 Molal & 19.5 & 0.130 & 19.4 & 0.040 \\
5 Molal Duplicate & 20.3 & 0.142 & 19.8 & 0.045 \\
\hline
\end{tabular}

\footnotetext{
${ }^{1}$ EchoTherm is a trademark of Torrey Pines Scientific, Inc., Carlsbad, California.
} 
Table 1. Average Temperature and $3 \sigma$ Standard Deviation for $20^{\circ} \mathrm{C}$ Experiments. ( 2 sheets)

\begin{tabular}{lcccc}
\hline Experiment & $\begin{array}{c}\text { Average Head } \\
\text { Space } \\
\text { Temperature }\left({ }^{\circ} \mathbf{C}\right)\end{array}$ & $\begin{array}{c}\text { Head Space } \\
\text { Temperature } \\
\text { Standard Deviation } \\
\mathbf{( 3 \sigma )}\end{array}$ & $\begin{array}{c}\text { Average Solution } \\
\text { Temperature }\left({ }^{\circ} \mathbf{C}\right)\end{array}$ & $\begin{array}{c}\text { Solution Temperature } \\
\text { Standard Deviation } \\
(\mathbf{3 \sigma})\end{array}$ \\
\hline 7.5 Molal & 20.0 & 0.139 & 19.6 & 0.042 \\
10 Molal & 19.9 & 0.140 & 19.6 & 0.050 \\
12.5 Molal & 20.2 & 0.138 & 19.8 & 0.051 \\
15 Molal & 20.0 & 0.140 & 19.6 & 0.048 \\
15 Molal Duplicate & 20.2 & 0.144 & 19.7 & 0.047 \\
17.5 Molal & 20.0 & 0.150 & 19.7 & 0.057 \\
20 Molal & 20.5 & 0.128 & 19.9 & 0.037 \\
22.5 Molal & 19.5 & 0.142 & 19.5 & 0.052 \\
25 Molal & 20.1 & 0.139 & 19.8 & 0.050 \\
25 Molal Duplicate & 19.8 & 0.123 & 19.6 & 0.045 \\
\hline
\end{tabular}

\subsection{TEMPERATURE CONTROL AT $60^{\circ} \mathrm{C}$}

For experiments conducted at $60{ }^{\circ} \mathrm{C}$, the water activity meter was heated using an analog laboratory oven (Quincy Labs, Inc., Model 10-180) manually set to $60^{\circ} \mathrm{C}$. The oven contained two shelves, and the top shelf was lowered to a position that put the water activity meter in the center of the oven. The oven was not temperature controlled and drifted throughout the set of experiments due to varying laboratory temperatures. For this reason, slight adjustments were made to the oven set point when it was observed that the average oven temperature drifted away from a desired temperature of $60{ }^{\circ} \mathrm{C}$. However, the oven temperature did not typically vary more than $1{ }^{\circ} \mathrm{C}$ while collecting a data set for an individual experiment. . tabulates the average temperature for each individual experiment.

Table 2. Average Temperature and $3 \sigma$ Standard Deviation for $60{ }^{\circ} \mathrm{C}$ Experiments. (2 sheets)

\begin{tabular}{lcccc}
\hline Experiment & $\begin{array}{c}\text { Average Head } \\
\text { Space } \\
\text { Temperature }\left({ }^{\circ} \mathbf{C}\right)\end{array}$ & $\begin{array}{c}\text { Head Space } \\
\text { Temperature } \\
\text { Standard Deviation } \\
\mathbf{( 3 \sigma )}\end{array}$ & $\begin{array}{c}\text { Average Solution } \\
\text { Temperature }\left({ }^{\circ} \mathbf{C}\right)\end{array}$ & $\begin{array}{c}\text { Solution Temperature } \\
\text { Standard Deviation } \\
(\mathbf{3 \sigma})\end{array}$ \\
\hline 2.5 Molal & 58.2 & 0.149 & 58.8 & 0.068 \\
5.0 Molal & 59.8 & 0.169 & 60.6 & 0.059 \\
5 Molal Duplicate & 58.7 & 0.220 & 60.4 & 0.093 \\
7.5 Molal & 59.5 & 0.212 & 60.2 & 0.071 \\
10 Molal & 60.7 & 0.129 & 62.0 & 0.060 \\
12.5 Molal & - & - & - & - \\
15 Molal & 60.5 & 0.135 & 61.7 & 0.063 \\
\hline
\end{tabular}


Table 2. Average Temperature and $3 \sigma$ Standard Deviation for $60^{\circ} \mathrm{C}$ Experiments. ( 2 sheets)

\begin{tabular}{lcccc}
\hline Experiment & $\begin{array}{c}\text { Average Head } \\
\text { Space } \\
\text { Temperature }\left({ }^{\circ} \mathbf{C}\right)\end{array}$ & $\begin{array}{c}\text { Head Space } \\
\text { Temperature } \\
\text { Standard Deviation } \\
\mathbf{( 3 \sigma )}\end{array}$ & $\begin{array}{c}\text { Average Solution } \\
\text { Temperature }\left({ }^{\circ} \mathbf{C}\right)\end{array}$ & $\begin{array}{c}\text { Solution Temperature } \\
\text { Standard Deviation } \\
(\mathbf{3 \sigma})\end{array}$ \\
\hline 15 Molal Duplicate & 60.9 & 0.177 & 63.0 & 0.062 \\
17.5 Molal & 60.7 & 0.167 & 62.6 & 0.079 \\
20 Molal & 59.9 & 0.151 & 61.3 & 0.064 \\
22.5 Molal & 60.7 & 0.549 & 61.2 & 0.046 \\
25 Molal & 60.8 & 0.490 & 62.6 & 0.282 \\
25 Molal Duplicate & 59.7 & 0.157 & 61.2 & 0.062 \\
\hline
\end{tabular}

\subsection{CALIBRATION SOURCE-NAOH SOLUTIONS}

$\mathrm{NaOH}$ solutions at various concentrations were used to test the accuracy and precision of the water activity meter. The water activity is strongly affected by the presence of sodium hydroxide ions with nearly the entire range of water activity (0.05-0.80) measurable with $\mathrm{NaOH}$ concentrations ranging from 25-5 molal, respectively. Table 3 is a tabulation of water activity of $\mathrm{NaOH}$ solutions at the temperatures of $20^{\circ} \mathrm{C}$ and $60^{\circ} \mathrm{C}$.

Table 3. NaOH Solution Concentrations and Estimated Water Activity.

\begin{tabular}{ccc}
\hline $\mathbf{N a O H}(\mathbf{m o l e} / \mathbf{k g})$ & $\mathbf{a}_{\mathbf{w}}$ at $20^{\circ} \mathbf{C}$ & $\mathbf{a}_{\mathbf{w}}$ at $60^{\circ} \mathbf{C}$ \\
\hline 0.00 & 1.00 & 1.00 \\
5.00 & 0.79 & 0.80 \\
10.00 & 0.50 & 0.55 \\
15.00 & 0.25 & 0.32 \\
20.00 & 0.11 & 0.16 \\
25.00 & 0.05 & 0.08 \\
\hline
\end{tabular}

The water activity for the $\mathrm{NaOH}$ solutions in Table 3 were determined from a correlation fit to both $20^{\circ} \mathrm{C}$ and $60{ }^{\circ} \mathrm{C}$ data originating from RPP-RPT-47795, Water Activity Data Assessment to be used in Hanford Waste Solubility Calculations, and "Water vapor partial pressures and water activities in potassium and sodium hydroxide solutions over wide concentration and temperature ranges," (Balej 1985), respectively. Both data sets at $20^{\circ} \mathrm{C}$ and $60{ }^{\circ} \mathrm{C}$ were fit with a Sigmoid function. The data and the fitted equations are plotted on Figure 2. The equation and fitted parameters are displayed in Equation 9 and Table 4, respectively. 
Figure 2. Water Activity Data for Aqueous NaOH Solutions.

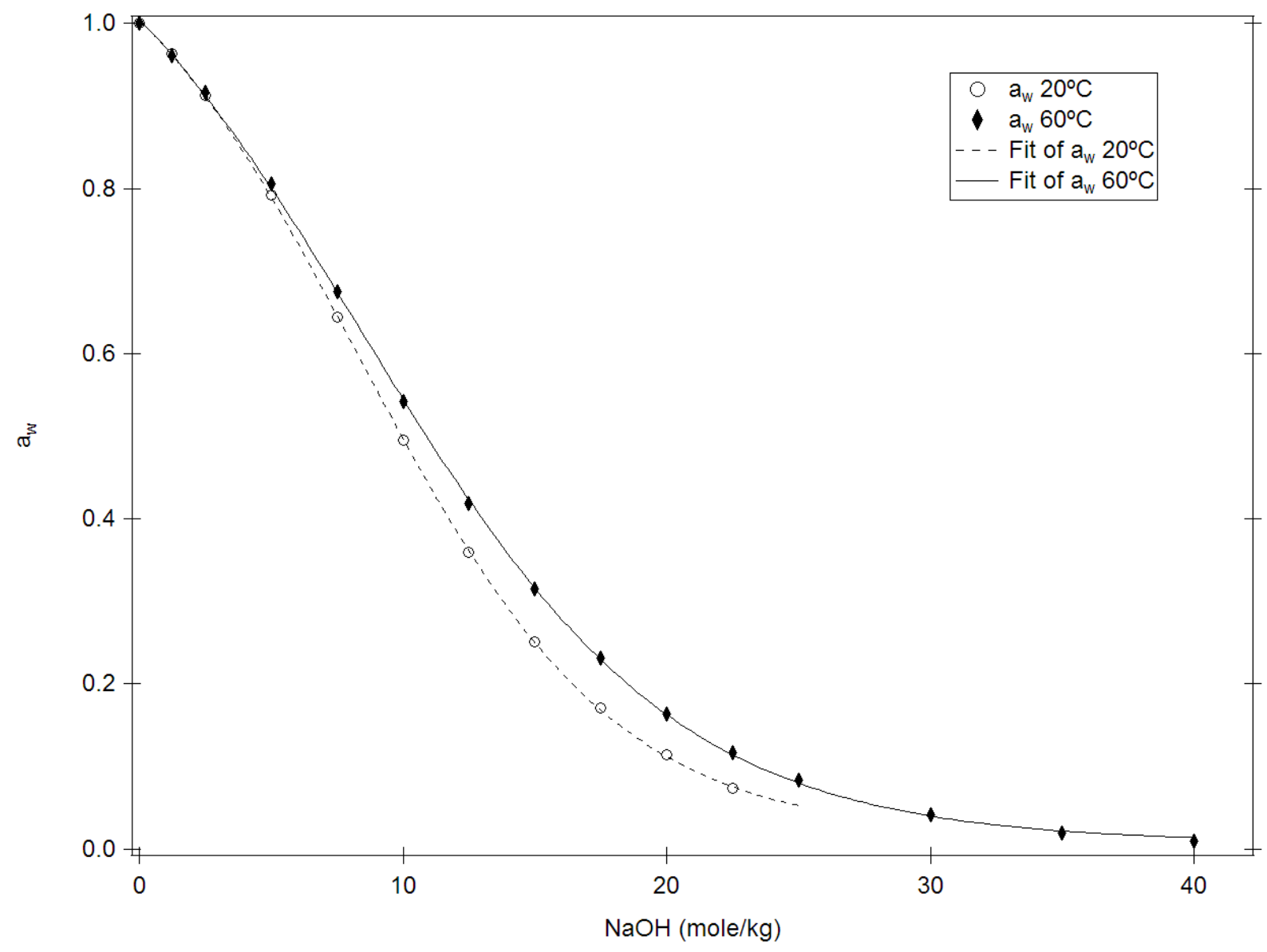

Equation 9. Sigmoid Regression Equation.

$$
a_{w}=\text { base }+\left[\frac{\max }{1+\exp \left(\frac{\text { xhalf }-N a O H}{\text { rate }}\right)}\right]
$$

Where:

$a_{w}=$ Water Activity

$\mathrm{NaOH}=\mathrm{NaOH}$ Concentration $\left(\right.$ mole $/ \mathrm{kg} \mathrm{H}_{2} \mathrm{O}$ ). 
Table 4. Water Activity Constants for Sigmoid Regression Equation.

\begin{tabular}{|c|c|c|}
\hline Constant & Value at $20^{\circ} \mathrm{C}$ & Value at $60^{\circ} \mathrm{C}$ \\
\hline base & $1.1825 \pm 0.00886$ & $1.2472 \pm 0.014$ \\
\hline $\max$ & $-1.1656 \pm 0.0114$ & $-1.2391 \pm 0.0156$ \\
\hline xhalf & $8.281 \pm 0.0771$ & $8.4124 \pm 0.153$ \\
\hline rate & $4.8474 \pm 0.0711$ & $5.9522 \pm 0.0962$ \\
\hline \multicolumn{3}{|c|}{ Quality of Fit } \\
\hline Chi Squared & $5.51378 \times 10^{-5}$ & $1.61845 \times 10^{-4}$ \\
\hline
\end{tabular}

Table 5 lists the concentrations of $\mathrm{NaOH}$ solutions used in each experiment. The whole number $\mathrm{NaOH}$ solutions originated from the Advanced Technologies and Laboratories International, Inc. (ATL) standards laboratory and are noted in Table 5 by ATL book number. These solutions were titrated to determine the standard concentration to one thousandths of a molal in concentration. The other solutions listed in Table 5 were made by mixing two similar masses of a higher concentration solution and a lower concentration solution. For example, the 7.5 molal $\mathrm{NaOH}$ solution was made by mixing $29.11 \mathrm{~g}$ of 5.097 molal solution with $29.37 \mathrm{~g}$ of 9.918 solution for a final $\mathrm{NaOH}$ concentration of 7.518 molal. The 2.5 molal solution was made by mixing $34.36 \mathrm{~g}$ of $18.2 \mathrm{Mohm}$ water with $45.13 \mathrm{~g}$ of 5.097 molal solution for a resulting concentration of 2.203 molal. A National Institute of Standards and Technology traceable balance was used to determine the masses of $\mathrm{NaOH}$ solutions used to make the resulting solution.

Table 5. NaOH Solutions Used for Each Experiment.

\begin{tabular}{|c|c|c|c|c|c|}
\hline $\begin{array}{l}\mathrm{NaOH} \\
\text { Solution }\end{array}$ & $\begin{array}{c}\text { Titrated } \\
\text { Concentration } \\
\left(\text { mole } / \mathrm{kg} \mathrm{H} \mathrm{H}_{2} \mathrm{O}\right)\end{array}$ & $\begin{array}{c}\text { ATL } \\
\text { Book } \\
\text { Number }\end{array}$ & $\begin{array}{c}\text { Mass of Lower } \\
\mathrm{NaOH} / \mathrm{H}_{2} \mathrm{O} \\
\text { Solution (g) }\end{array}$ & $\begin{array}{c}\text { Mass of Upper } \\
\text { NaOH Solution (g) }\end{array}$ & $\begin{array}{l}\mathrm{NaOH} \text { Concentration } \\
\left(\mathrm{mole} / \mathrm{kg} \mathrm{H}_{2} \mathrm{O}\right)\end{array}$ \\
\hline 2.5 & & & $34.36^{\mathrm{a}}$ & 45.13 & 2.203 \\
\hline 5 & 5.097 & $141 \mathrm{~N} 22 \mathrm{~A}$ & - & - & 5.097 \\
\hline 7.5 & & & 29.11 & 29.37 & 7.518 \\
\hline 10 & 9.918 & $143 \mathrm{~N} 22 \mathrm{~A}$ & - & - & 9.918 \\
\hline 12.5 & & & 33.83 & 39.63 & 12.57 \\
\hline 15 & 14.837 & $144 \mathrm{~N} 22 \mathrm{~A}$ & - & - & 14.84 \\
\hline 17.5 & & & 28.92 & 30.21 & 16.57 \\
\hline 20 & 18.223 & $145 \mathrm{~N} 22 \mathrm{~A}$ & - & - & 18.22 \\
\hline 22.5 & & & 34.24 & 43.75 & 20.85 \\
\hline 25 & 22.913 & $146 \mathrm{~N} 22 \mathrm{~A}$ & - & - & 22.91 \\
\hline
\end{tabular}

${ }^{\mathrm{a}} \mathrm{A}$ mass of $18.2 \mathrm{Mohm}$ distilled water containing no $\mathrm{NaOH}$ was added. 


\section{RESULTS}

\section{1 $20^{\circ} \mathrm{C}$ RESULTS USING HUMIDITY SENSOR ONLY}

The water activity of several $\mathrm{NaOH}$ solutions at various concentrations as determined using only the humidity probe at $20^{\circ} \mathrm{C}$ is tabulated in Table 6 and displayed in Figure 3. For all $\mathrm{NaOH}$ concentrations below 22.5 molal, the system showed a slight negative bias with percent recovery ranging from a low of $89.1 \%$ to a high of $99.1 \%$. A positive bias existed for $\mathrm{NaOH}$ concentrations of 22.5 and 25 molal. The largest bias was at a $\mathrm{NaOH}$ concentration of 25 molal with a percent recovery of 118 to $122 \%$. In general, the accuracy of the water activity measurement was good for $\mathrm{NaOH}$ solution concentrations ranging from 2.5-22.5 molal. The regressed 1:1 line showed near perfect agreement with a slope and intercept of $0.98 \pm 0.00050$ and $0.0012 \pm 0.00022$ (Inset of Figure 3 ). The fit was nearly perfect with a coefficient of determination $\left(\mathrm{R}^{2}\right)$ value of 1.02 . However, an inspection of individual points demonstrated that some deviation from the fit was present with the agreement of water activity data below 0.2 . The results of the duplicates also demonstrated that this instrument arrangement at $20{ }^{\circ} \mathrm{C}$ showed good precision. Duplicate tests were conducted at $\mathrm{NaOH}$ solution concentrations of 5,15 , and 25 molal. The greatest reported percent difference (RPD) of the three duplicates was $3.41 \%$ at a $\mathrm{NaOH}$ solution concentration of 25 molal, which is within an acceptable limit of $\pm 5 \%$. Generally, this method is both accurate and precise in determining the water activity of electrolyte solutions with a water activity between 0.20 and less than 1.00 .

Table 6. Tabulated Water Activity of NaOH Solutions Using Only a Humidity Probe at a Temperature of $20^{\circ} \mathrm{C}$.

\begin{tabular}{ccccc}
\hline Experiment & NaOH (mole/kg) & Mean $\mathbf{a}_{\mathbf{w}}(\mathbf{3 \sigma})$ & \% Recovery & RPD of Duplicates \\
\hline 2.5 & 2.20 & $0.87 \pm 0$ & 94.4 & - \\
5 & 5.10 & $0.77 \pm 0.0011$ & 98.1 & 0.578 \\
5_Dup & 5.10 & $0.77 \pm 0.0014$ & 97.5 & - \\
7.5 & 7.52 & $0.64 \pm 0.0019$ & 99.1 & - \\
10 & 9.92 & $0.49 \pm 0.0134$ & 97.4 & - \\
12.5 & 12.57 & $0.35 \pm 0.0014$ & 96.6 & - \\
15 & 14.84 & $0.25 \pm 0.0013$ & 95.8 & 1.23 \\
$15 \_D u p$ & 14.84 & $0.25 \pm 0.0012$ & 97.0 & - \\
17.5 & 16.57 & $0.18 \pm 0$ & 90.4 & - \\
20 & 18.22 & $0.13 \pm 0.0013$ & 89.1 & - \\
22.5 & 20.85 & $0.1 \pm 0.0091$ & 102 & - \\
25 & 22.91 & $0.08 \pm 0.0012$ & 118 & 3.41 \\
$25 \_D u p$ & 22.91 & $0.09 \pm 0.0012$ & 122 & - \\
\hline
\end{tabular}


Figure 3. Measured and Literature Values of Water Activity of $20{ }^{\circ} \mathrm{C} \mathrm{NaOH}$ Solutions at Varying Concentrations Using a Humidity Probe Only.

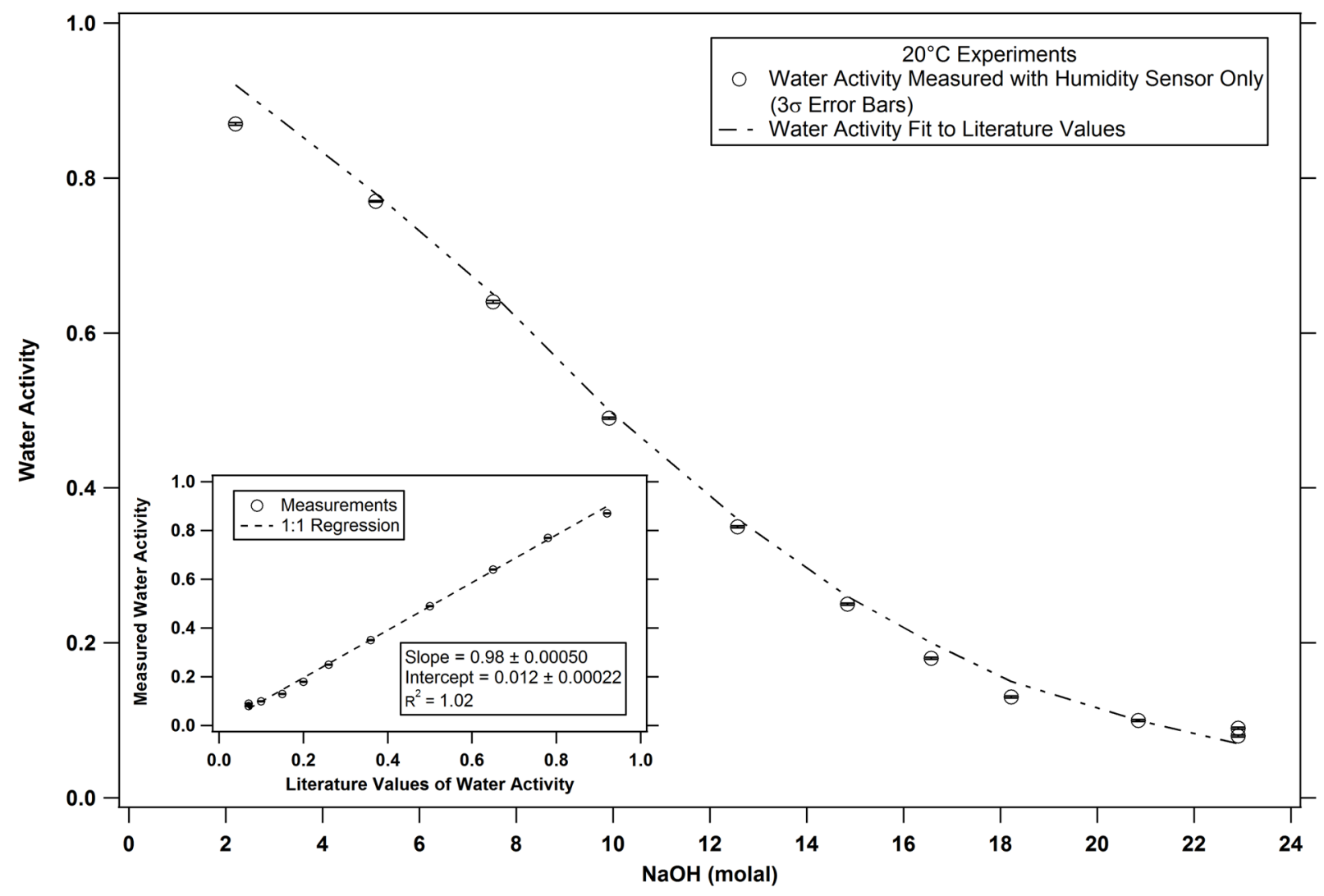

\section{$3.2 \quad 20{ }^{\circ} \mathrm{C}$ RESULTS USING HUMIDITY SENSOR AND TEMPERATURE SENSOR}

The water activity was also determined using both a humidity probe and temperature probe. The humidity probe was used to determine the vapor pressure in the head space, and the temperature probe was used to determine the temperature of the $\mathrm{NaOH}$ solution, ultimately calculating the saturated water vapor of pure water. The measured water activity of the varying concentrations of $\mathrm{NaOH}$ solution demonstrated good agreement with literature values as shown in Figure 4. An inspection of the figure shows little evidence of bias present in the measurement as the data fall in no regular pattern around the literature values (dashed line). This was also confirmed by the 1:1 regression of the measured data plotted against literature values (Inset of Figure 4). It demonstrates good agreement over the range with linear regression having a slope and intercept of $0.96 \pm 0.0018$ and $0.011 \pm 0.00043$, respectively. The fit of the regression had an $\mathrm{R}^{2}$ value of 0.93 showing good fit. The system accurately predicted the water activity of the $\mathrm{NaOH}$ solutions varying in concentration from 2.89 to 20.85 molal with the percent recovery not exceeding $100 \pm 4 \%$ as tabulated in Table 7 . The measured water activity of the $\mathrm{NaOH}$ solution at a concentration of 22.91 showed poor results with the percent recovery ranging between 120 and $123 \%$. The RPD determinations of water activity in the duplicate $\mathrm{NaOH}$ samples demonstrated good agreement with the RPD never exceeding 3\%. These results demonstrate the precision of 
the instrument is consistent throughout the range of water activity measured. In general, the results suggest that this configuration is accurate and precise when measuring the water activity of electrolyte solutions with a water activity ranging from 0.20 to less than 1.00 .

Table 7. Tabulated Water Activity of NaOH Solutions Using Humidity Probe in Conjunction with a Temperature Probe at a Temperature of $20{ }^{\circ} \mathrm{C}$.

\begin{tabular}{ccccc}
\hline Experiment & NaOH (mole/kg) & Mean $\mathbf{a}_{\mathbf{w}}(\mathbf{3 \sigma})$ & \% Recovery & RPD of Duplicates \\
\hline 2.5 & 2.20 & $0.93 \pm 0.0112$ & 101 & - \\
5 & 5.10 & $0.78 \pm 0.0072$ & 99 & 1.90 \\
5_Dup & 5.10 & $0.79 \pm 0.0078$ & 101 & - \\
7.5 & 7.52 & $0.65 \pm 0.0065$ & 101 & - \\
10 & 9.92 & $0.5 \pm 0.0097$ & 99 & - \\
12.5 & 12.57 & $0.35 \pm 0.0097$ & 99 & - \\
15 & 14.84 & $0.25 \pm 0.003$ & 98 & 1.91 \\
15 Dup & 14.84 & $0.26 \pm 0.0031$ & 100 & - \\
17.5 & 16.57 & $0.18 \pm 0.0026$ & 92 & - \\
20 & 18.22 & $0.14 \pm 0.002$ & 92 & - \\
22.5 & 20.85 & $0.1 \pm 0.0086$ & 102 & - \\
25 & 22.91 & $0.09 \pm 0.0017$ & 120 & - \\
$25 \_D u p$ & 22.91 & $0.09 \pm 0.0017$ & 123 & - \\
\hline
\end{tabular}


Figure 4. Measured and Literature Values of Water Activity of $20^{\circ} \mathrm{C} \mathrm{NaOH}$ Solutions at Varying Concentrations Using a Humidity Probe and Temperature Probe.

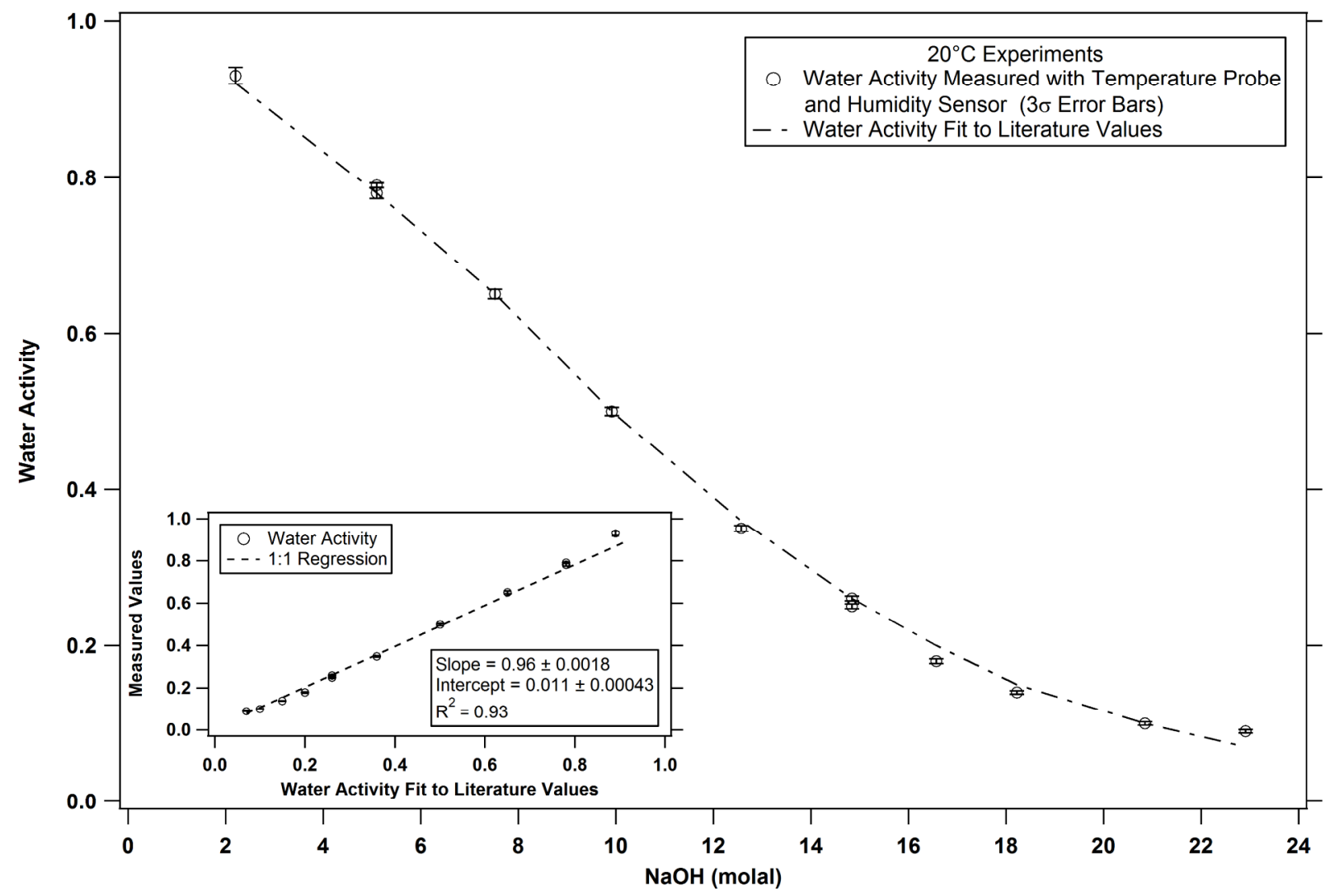

\section{$3.3 \quad 60^{\circ} \mathrm{C}$ RESULTS USING HUMIDITY SENSOR ONLY}

The water activity of $\mathrm{NaOH}$ solutions of varying concentrations was also determined at a temperature of $60^{\circ} \mathrm{C}$ using the humidity probe only. Figure 5 shows the values determined from the experiment (circles) and literature values of these data (dashed line). An inspection of the figure clearly illustrates that the experimentally determined values have a positive bias as compared to the literature values. This is also verified by the 1:1 analysis of the data (inset of Figure 5) as compared to the literature values. A linear regression of the data indicated a positive bias with the slope and intercept having values of $1.04 \pm 0.00065$ and $0.030 \pm 0.00024$, respectively. The fit had an $\mathrm{R}^{2}$ value of 0.96 . The percent recovery of each point shows that the water activity was overestimated over the range of $\mathrm{NaOH}$ solution with percent recovery ranging from $108-146 \%$ of the literature values. The percent recovery was the greatest at $\mathrm{NaOH}$ solution concentrations of 22.5 and 25.0 molal with percent recoveries of 121 and $146 \%$, respectively. The duplicate analysis ranged from $2.02 \%$ to $5.35 \%$ indicating good precision. Again this configuration demonstrated good accuracy and precision determining the water activity of electrolyte solutions through a range of 0.20 to less than 1.00 . 
Table 8. Tabulated Water Activity of $\mathrm{NaOH}$ Solutions Using Only a Humidity Probe at a Temperature of $60^{\circ} \mathrm{C}$.

\begin{tabular}{ccccc}
\hline Experiment & NaOH (mole/kg) & Mean $\mathbf{a}_{\mathbf{w}}(\mathbf{3 \sigma})$ & \% Recovery & RPD of Duplicates \\
\hline $2.5 \mathrm{~m}$ & 2.20 & $0.99 \pm 0.0045$ & 108 & - \\
$5 \mathrm{~m}$ & 5.10 & $0.86 \pm 0.0016$ & 107 & 5.35 \\
$5 \mathrm{~m} \_$Dup & 5.10 & $0.9 \pm 0.0038$ & 113 & - \\
$7.5 \mathrm{~m}$ & 7.52 & $0.73 \pm 0.0026$ & 109 & - \\
$10 \mathrm{~m}$ & 9.92 & $0.6 \pm 0.0017$ & 109 & - \\
$12.5 \mathrm{~m}$ & 12.57 & - & - & - \\
$15 \mathrm{~m}$ & 14.84 & $0.36 \pm 0.0013$ & 110 & 5.07 \\
$15 \mathrm{~m} \_$Dup & 14.84 & $0.37 \pm 0.0018$ & 116 & - \\
$17.5 \mathrm{~m}$ & 16.57 & $0.3 \pm 0.0102$ & 114 & - \\
$20 \mathrm{~m}$ & 18.22 & $0.23 \pm 0.001$ & 108 & - \\
$22.5 \mathrm{~m}$ & 20.85 & $0.17 \pm 0.0049$ & 121 & - \\
$25 \mathrm{~m}$ & 22.91 & $0.16 \pm 0.0013$ & 146 & 2.02 \\
$25 \mathrm{~m} \_$Dup & 22.91 & $0.15 \pm 0.001$ & 143 & - \\
\hline
\end{tabular}

Figure 5. Measured and Literature Values of Water Activity of $60^{\circ} \mathrm{C} \mathrm{NaOH}$ Solutions at Varying Concentrations Using a Humidity Probe Only.

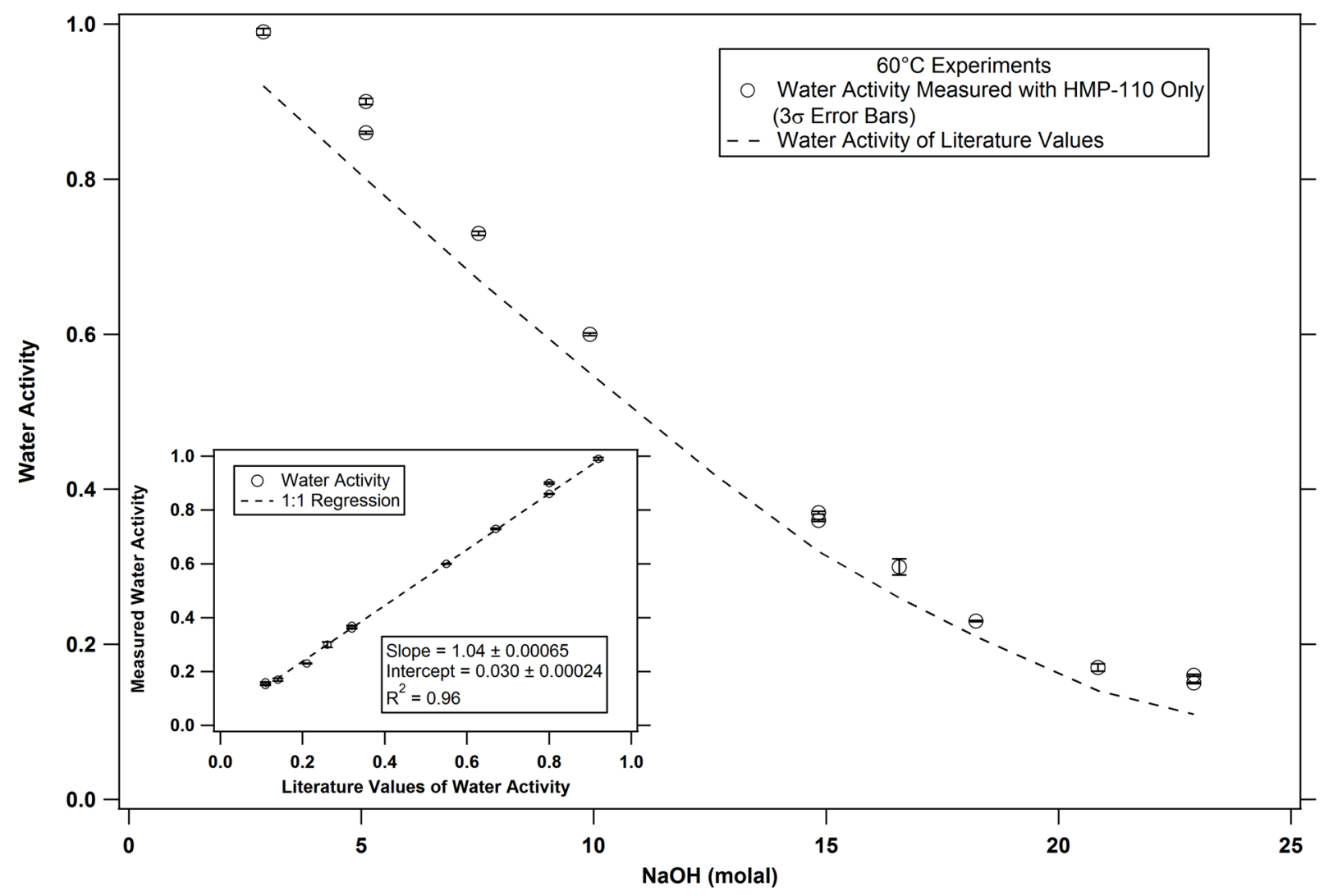




\section{$3.460^{\circ} \mathrm{C}$ RESULTS USING HUMIDITY SENSOR AND TEMPERATURE SENSOR}

By incorporating the solution temperature measurement into the calculation of the water activity, the determination of the water activity of the $\mathrm{NaOH}$ solution proved more accurate. The results of this experiment are presented in Figure 6. The plot showed that the measured data agree well with the literature values with the possibility of a slight positive bias. However, a 1:1 regression of the data (Figure 6, inset) suggests that the bias is inconsequential with the regression having a slope and intercept of $1.00 \pm 0.0015$ and $0.023 \pm 0.00045$, respectively. The $\mathrm{R}^{2}$ value of the fit was 0.96 . Table 9 is a tabulation of the results and shows that in most cases the percent recovery was less than 5\%, except for the 2.5, 22.5, and 25 molal solutions. Also, the precision of the measurement was outstanding with RPD of the duplicates at or around $1 \%$. In general, this method was effective when measuring the water activity in the range of 0.20 to less than 1.00 .

Table 9. Tabulated Water Activity of NaOH Solutions Using a Humidity Probe and Temperature Probe at a Temperature of $60^{\circ} \mathrm{C}$.

\begin{tabular}{ccccc}
\hline Experiment & NaOH (mole/kg) & Mean $\mathbf{a}_{\mathbf{w}}(\mathbf{3 \sigma} \boldsymbol{\sigma})$ & \% Recovery & RPD of Duplicates \\
\hline $2.5 \mathrm{~m}$ & 2.20 & $0.97 \pm 0.0069$ & 108 & - \\
$5 \mathrm{~m}$ & 5.10 & $0.82 \pm 0.0073$ & 103 & 1.14 \\
$5 \mathrm{~m} \_$Dup & 5.10 & $0.83 \pm 0.0064$ & 105 & - \\
$7.5 \mathrm{~m}$ & 7.52 & $0.71 \pm 0.0077$ & 105 & - \\
$10 \mathrm{~m}$ & 9.92 & $0.57 \pm 0.0041$ & 103 & - \\
$12.5 \mathrm{~m}$ & 12.57 & - & - & - \\
$15 \mathrm{~m}$ & 14.84 & $0.34 \pm 0.0026$ & 104 & 0.93 \\
$15 \mathrm{~m} \_$Dup & 14.84 & $0.34 \pm 0.0028$ & 105 & - \\
$17.5 \mathrm{~m}$ & 16.57 & $0.27 \pm 0.0113$ & 105 & - \\
$20 \mathrm{~m}$ & 18.22 & $0.21 \pm 0.0021$ & 102 & - \\
$22.5 \mathrm{~m}$ & 20.85 & $0.17 \pm 0.0086$ & 118 & - \\
$25 \mathrm{~m}$ & 22.91 & $0.14 \pm 0.0018$ & 134 & 1.09 \\
$25 \mathrm{~m} \_$Dup & 22.91 & $0.14 \pm 0.0016$ & 133 & - \\
\hline
\end{tabular}


Figure 6. Measured and Literature Values of Water Activity of $60{ }^{\circ} \mathrm{C} \mathrm{NaOH}$ Solutions at Varying Concentrations Using a Humidity Probe and Temperature Probe.

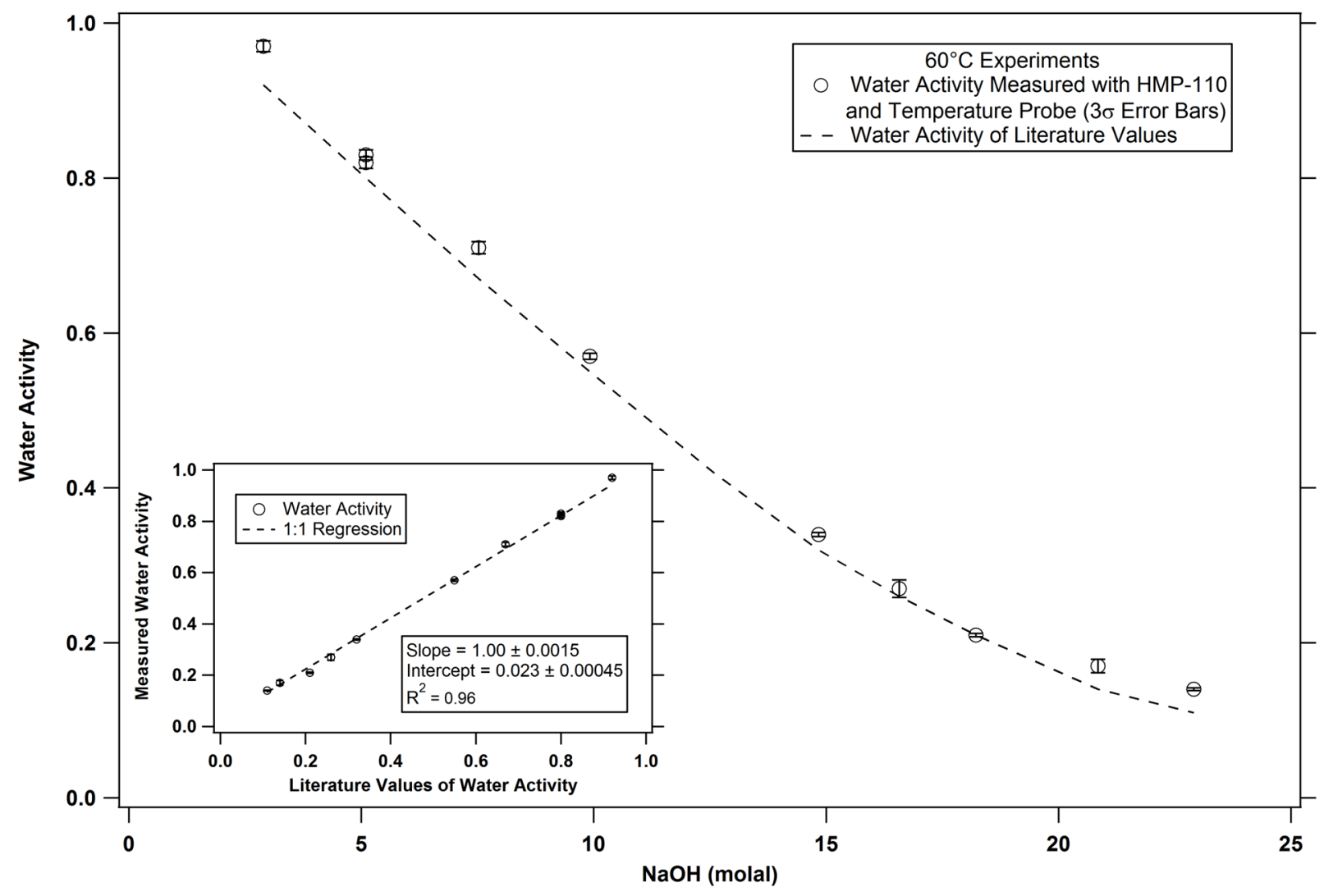

\subsection{METHOD ANALYSIS}

As explained earlier in this report, the water activity was determined using one of two methods: 1) by humidity probe only and 2) by humidity probe in conjunction with a solution temperature probe. Each method was performed in unison for accurate method comparison. For the purpose of this discussion, the method which implemented the humidity probe only will be referred as Method 1, and the method which used both the humidity probe and temperature probe will be referred to as Method 2.

Some important factors that determined the effectiveness of the method were the percent recovery of the measured data compared to the literature, RPD of the duplicate measurements of identical $\mathrm{NaOH}$ solutions, and the linear fit of a 1:1 regression of the measured data compared to the literature data. The percent recovery provides an indication of the accuracy of the method for each experiment performed while the duplicate analysis provides an indication of the precision for three $\mathrm{NaOH}$ solutions of a temperature and method of interest. The slope of the 1:1 regression provides an indication of trending bias for a range of $\mathrm{NaOH}$ solutions for specific temperature and method. The intercept provides an indication of a general bias for a particular method at a specific temperature. 
An inspection of the results of the two methods used to determine the water activity at $20^{\circ} \mathrm{C}$ shows that there is no superior method. For the $20^{\circ} \mathrm{C}$ experiments using Method 1, the percent recovery ranged between 89 and $122 \%$ with a mean percent recovery of $100 \pm 9.0 \%$ (Table 10) while the percent recovery of the experiments conducted using Method 2 ranged between 102 and $134 \%$ with a mean percent recovery of $102 \pm 26.8 \%$. These results demonstrate that Method 1 is slightly more accurate than Method 2. However, Method 1 was not as precise as Method 2 as demonstrated by the standard deviation of the mean of the RPD duplicates. Also, the Method 1 slope of the 1:1 regression suggests that the method underestimates water activity with increasing values of water activity.

Table 10. Consolidated Results of $20^{\circ} \mathrm{C}$ Water Activity Experiments.

\begin{tabular}{|c|c|c|c|c|c|}
\hline \multirow[b]{2}{*}{ Method } & \multirow{2}{*}{$\begin{array}{c}\text { Mean \% Recovery } \\
(3 \sigma)\end{array}$} & \multirow{2}{*}{ 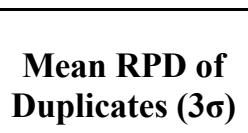 } & \multicolumn{3}{|c|}{ 1:1 Regression Parameters } \\
\hline & & & Slope & Intercept & $\mathbf{R}^{2}$ \\
\hline 1) Humidity Probe Only & $100 \pm 27.4$ & $2 \pm 3.6$ & $\begin{array}{l}0.99 \pm \\
0.0014\end{array}$ & $\begin{array}{l}0.0054 \pm \\
0.00083\end{array}$ & 1.00 \\
\hline $\begin{array}{l}\text { 2) Humidity Probe in } \\
\text { Conjunction with a } \\
\text { Temperature Probe }\end{array}$ & $102 \pm 26.8$ & $2 \pm 1.2$ & $\begin{array}{l}1.00 \pm \\
0.0012\end{array}$ & $\begin{array}{c}0.0029 \pm \\
0.00038\end{array}$ & 0.96 \\
\hline
\end{tabular}

Method 2 proved to be the more effective method for determining the water activity of $\mathrm{NaOH}$ solutions at $60^{\circ} \mathrm{C}$. Both methods had positive bias, but the bias of Method 2 was nearly half the bias of Method 1 with a mean percent recovery of $110 \pm 33.4$ vice $117 \pm 37.7$. Also, Method 2 proved more precise with a mean RPD of $1 \pm 0.3$ vice the Method 1 average RPD of $4 \pm 4.5$. Method 1 also showed a trending positive bias, which indicated a nonlinear response to varying water activity.

Table 11. Consolidated Results of $60^{\circ} \mathrm{C}$ Water Activity Experiments.

\begin{tabular}{|c|c|c|c|c|c|}
\hline \multirow{2}{*}{ Method } & \multirow{2}{*}{$\begin{array}{c}\text { Mean \% } \\
\text { Recovery (3б) }\end{array}$} & \multirow{2}{*}{ 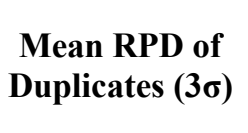 } & \multicolumn{3}{|c|}{ 1:1 Regression Parameters } \\
\hline & & & Slope & Intercept & $\mathbf{R}^{2}$ \\
\hline Humidity Probe Only & $117 \pm 38.2$ & $4 \pm 4.5$ & $\begin{array}{c}1.04 \pm \\
0.00065\end{array}$ & $\begin{array}{l}0.029 \pm \\
0.00024\end{array}$ & 0.95 \\
\hline $\begin{array}{l}\text { Humidity Probe in } \\
\text { Conjunction with a } \\
\text { Temperature Probe }\end{array}$ & $110 \pm 33.4$ & $1 \pm 0.3$ & $\begin{array}{l}1.00 \pm \\
0.0016\end{array}$ & $\begin{array}{c}0.022 \pm \\
0.0 .00045\end{array}$ & 0.96 \\
\hline
\end{tabular}




\section{CONCLUSIONS}

The water activity of $\mathrm{NaOH}$ solutions ranging in concentration from 2.203 molal to 22.913 molal was determined using a custom water activity meter with a humidity probe only (Method 1) or a humidity probe in conjunction with a temperature probe (Method 2). The water activity of the range of $\mathrm{NaOH}$ solutions was determined at equilibrium temperatures of $20^{\circ} \mathrm{C}$ and $60{ }^{\circ} \mathrm{C}$. Both methods were effective in determining the water activity through a range of $\approx 0.20$ to 0.93 for a temperature of $20{ }^{\circ} \mathrm{C}$ while only Method 2 was effective in determining the water activity though a range of 0.21 to 0.97 at a temperature of $60{ }^{\circ} \mathrm{C}$.

In application, Method 2 should be used to determine the water activity of the tank waste supernates as the solution temperature probe can accurately determine the solution temperature. Using Method 1, the actual solution temperature is not determined, but is assumed to be the same as the head space temperature. However, if cross contamination of samples is of concern then Method 1 can be used as no sensor comes in contact with the sample. Ultimately, the water activity meter configuration implemented during determination of water activity should be based on experimental variables.

\section{REFERENCES}

Balej, J., 1985, "Water vapor partial pressures and water activities in potassium and sodium hydroxide solutions over wide concentration and temperature ranges," Int. J. Hydrogen Energy, Vol. 10, No. 4, pp 233-243.

LAB-PLN-11-00012, 2011, Testing and Validation of an Enhanced Acquisition and Control System, Rev. 0, Washington River Protection Solutions LLC, Richland, Washington.

RPP-RPT-47795, 2011, Water Activity Data Assessment to be used in Hanford Waste Solubility Calculations, Rev. 3, EnergySolutions LCC, Richland, Washington. 
LAB-RPT-13-00006

\section{APPENDIX A}

Linear Regressions Engineering Calculation 
LAB-RPT-13-00006

Appendix A

Title: Multiple Regressions for Water Activity Calculations

Engineer/Analyst: Jacob McCoskey

Checker: Richard Wyrwas

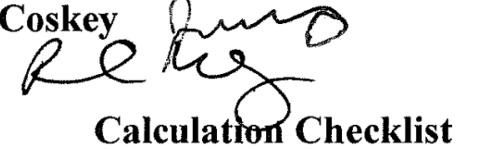

Date: $\begin{aligned} & \text { Page } 1 \text { of 20 } \\ & \frac{8 / 29 / 13}{8 / 29 / 13} \\ & \text { Date: }\end{aligned}$

Calculation Checklist

Calculation Title/Subject: Multiple Regressions for Water Activity Calculations

Scope of Review:

Engineer/Analyst

Organization Manager

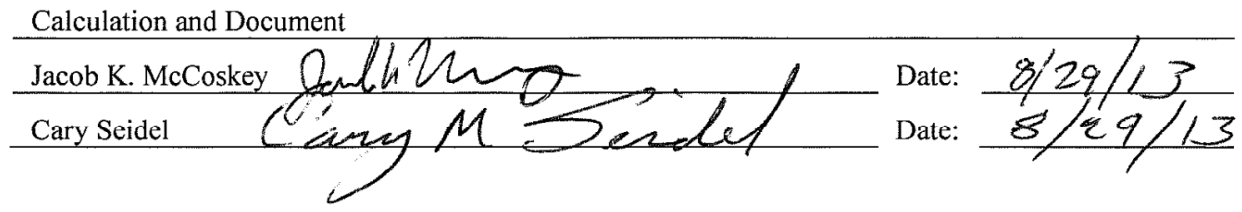

Yes $\mathrm{No}^{*} \mathrm{NA}^{*}$

$\left[\begin{array}{llll}Y & {[}\end{array}\right]$ [ ]

The objective/purpose of the calculation is clearly stated and the problem is completely defined by the purpose statement.

[V] [ ] [ ] b. Analytical and technical approaches and results are reasonable and appropriate.

[V [ ] [ ] c. Input data are adequately described, referenced to their source, and checked for consistency with original source information.

[ 6 [ ] [ ] d. Necessary assumptions are reasonable, explicitly stated, and supported. Assumptions requiring verification prior to use are clearly stated and identified/tracked using TBD/HOLD numbers.

[4 [ ] [ ] e. For both qualitative and quantitative data, uncertainties are recognized and discussed and the data is presented in a manner to minimize design interpretations.

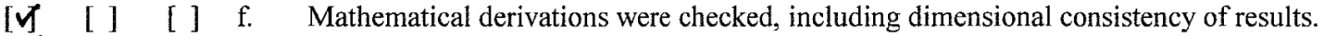

[ 7 [ ] [ ] g. Calculations are sufficiently detailed such that a technically qualified person can understand the

[ ] [ ] M h. Hand and MathCAD® calculations were verified, including review that correct input data are used, formulae correctly interpret intended expressions, correct units are used, and results are reasonable and appropriate.

[V [ ] [ [ i. Software applications used are identified by the program name and version/release number, both on the calculation cover sheet and in the body of the document.

[ ${ }^{\prime}$ [ ] [ ] j. Software input data is identified and/or attached/included, the input data is correct, and consistent with the calculation document.

[V] [ ] [ ] k. Software output is consistent with the input and with the results reported in the calculation document.

[V [ ] [ ] l. Software verification and validation are addressed adequately in accordance with TFC-BSM-IRM HSC-01. Software verification documentation is noted on the calculation cover sheet and in the body of the document as included in the calculation document or a reference is provided to separate verification documentation.

[ ] [ ] [ $\mathrm{m}$. Spreadsheets used in the calculation are identified, verified, and documented in accordance with TFCENG-DESIGN_C-32. Reference to the corresponding spreadsheet verification form is provided on the calculation cover sheet and in the body of the calculation.

[V [ ] [ ] n. Data or results presented in tables and graphs have been checked against original source.

[V [ ] [ ] o. Unit conversions are correct and consistent.

[M [ ] [ ] p. The number of significant digits is appropriate and consistent.

M [ ] [ ] q. Limits/criteria/guidelines applied to the analysis results are appropriate and referenced. Limits/criteria/guidelines were checked against references.

[V [ ] [ ] r. Conclusions are consistent with analytical results and applicable limits.

[V [ ] [ ] s. Results and conclusions address all points in the purpose.

[V [ ] [ ] t. Referenced documents are retrievable or otherwise available and the version or revision of each reference is cited.

[V] [ ] [ ] u. The document was prepared in accordance with Attachment A, "Calculation Format and Preparation Instructions," of TFC-ENG-DESIGN-C-10.

[ 4 [ ] [ ] v. Impacts on requirements have been assessed and change documentation initiated to incorporate

[revisions to affected documents, as appropriate.

[V] [ ] [ ] w. All checker comments have been dispositioned and the design media matches the calculations.

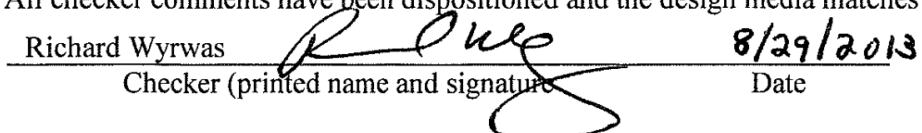

* If less than the entire calculation was checked, the scope of the check should be discussed. If any blocks are checked "No" or "NA", an explanation must be provided here or attached 
LAB-RPT-13-00006

Appendix A

Title: Multiple Regressions for Water Activity Calculations

Engineer/Analyst: Jacob McCoskey foul fin 7

Checker: Richard Wyrwas

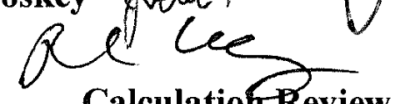

Page 2 of 20

Date: $8 / 24 / 13$

Date: $8-2 \$ 13$

Calculation Review

Subject: Multiple Regressions for Water Activity Calculations

The subject document has been reviewed by the undersigned

The reviewer reviewed and verified the following items as applicable.

Documents Reviewed: Multiple Regressions for Water Activity Calculations

Analysis Performed By: Richard Wyrwas

Sections Verified:

- Design Input

- Basic Assumptions

- Approach/Design Methodology

- Consistency with item or document supported by the calculation

- Conclusion/Results interpretation

Exceptions of Checklist:

- For item h., the checklist was marked NA as the calculations were performed using IGOR Pro and not by MathCAD or hand.

- For item i., the checklist was marked NA as the engineering calculation is embedded in another document and by procedure, a cover sheet is not required.

- For item m., the checklist was marked NA as the calculations were performed using IGOR Pro and not Microsoft Excel.

Reviewer (printed name, signature, and date) Richaud wy was 
LAB-RPT-13-00006

Appendix A

Title: Multiple Regressions for Water Activity Calculations

Engineer/Analyst: Jacob McCoskey

Checker: Richard Wyrwas
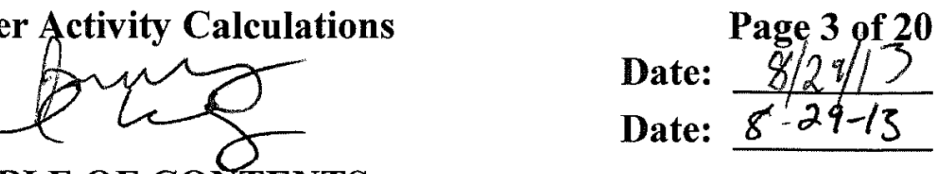

TABLE OF CONTENTS

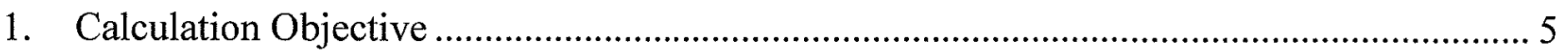

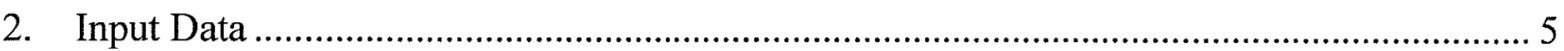

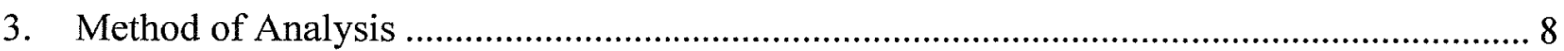

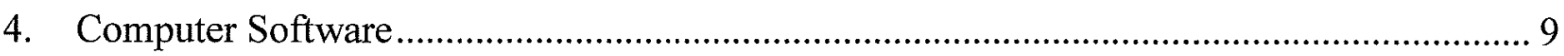

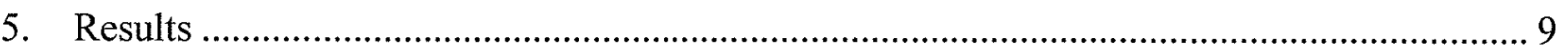

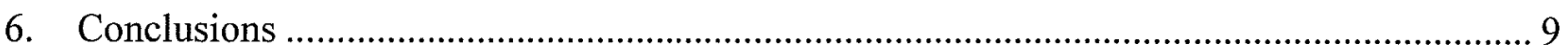

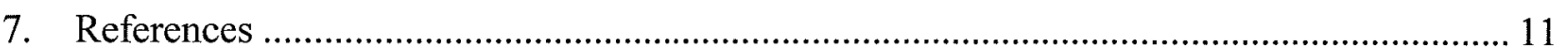

Appendix 1. IGOR Output of Sigmoid Regressions......................................................... 12

Appendix 2. IGOR Output of Lineat Regressions ................................................................ 13

Appendix 3. Results of Sigmoid Regression Check Using Origin Pro Version 9.00 ................... 15

Appendix 4. Results Linear Regression check using Origin Pro Version 9.00 ……..................... 17

\section{LIST OF TABLES}

Table 1. Water Activity Literature Data, International Critical tables, 1928 ................................ 6

Table 2. Data Values for 1:1 Regression Calculation............................................................... 7

Table 3. Results of Sigmoid Regression of Literature $\mathrm{NaOH}$ Solution Water Activity Data ....... 9

Table 4. Experiment Results of $1: 1$ Regressions .......................................................................... 9

\section{LIST OF FIGURES}

Figure A-1. HMP-110 Only at $20^{\circ} \mathrm{C}$ 17

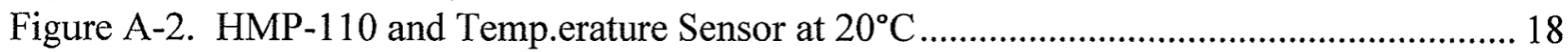

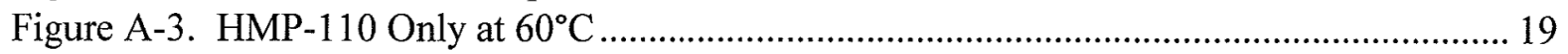

Figure A-4. HMP-1 10 and Temp.erature Sensor at $60^{\circ} \mathrm{C}$..................................................... 20 
LAB-RPT-13-00006

Appendix A

Title: Multiple Regressions for Water Activity Calculations Engineer/Analyst: Jacob McCoskey

Checker: Richard Wyrwas

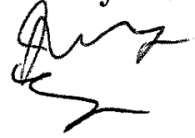

Abbreviations and Acronyms

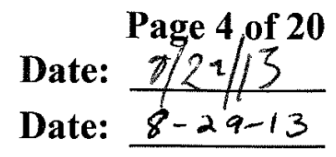

a

Linear Regression Intercept

b

Linear Regression Slope

$\mathrm{R}^{2}$

Coefficient of Determination

V_r2

Coefficient of Determination as reported by IGOR

Units

${ }^{\circ} \mathrm{C}$

Degrees Celsius 
LAB-RPT-13-00006

Appendix A

Title: Multiple Regressions for Water Activity Calculations

Engineer/Analyst: Jacob McCoskey

Page 5of 20
Date: $\frac{8 / 29 / 13}{8-29-13}$
Date:

\section{CALCULATION OBJECTIVE}

1) The first objective of this calculation was to determine the sigmoid regression of water activity at both $20^{\circ} \mathrm{C}$ and $60^{\circ} \mathrm{C}$ as a function of $\mathrm{NaOH}$ concentration in molality (aw $=$ $f([\mathrm{NaOH}]))$. This equation will be used to estimate the actual water activity of several $\mathrm{NaOH}$ solutions used in the laboratory experiment described in document LAB-PLN-1100012 Rev. 0, "Testing and Validation of an Enhanced Data Acquisition and Control System." The actual water activity values calculated using the sigmoid function will be compared to measured water activity values collected using the Enhanced Data Acquisition and Control System (EDAQS).

2) The second objective of this calculation document was to determine the slope and intercept of a linear regression of measured sodium hydroxide solution water activity data compared to literature data. The water activity of sodium hydroxide solutions varying in concentration was determined using a water activity meter in two configurations.

Configuration 1 included a humidity probe that determined the water vapor pressure of the head space assuming the head space temperature was in thermal equilibrium with the sodium hydroxide solution. Configuration 2 also incorporated the humidity probe to determine vapor pressure of the head space, but also included a temperature sensor to determine the temperature of the sodium hydroxide solution. The water activity of 10 sodium hydroxide solutions ranging from 2.5 to 25 molal in concentration was determined using each meter configuration. Also, the water activity was determined for sodium hydroxide solutions at both $20^{\circ} \mathrm{C}$ and $60^{\circ} \mathrm{C}$ using each of the configurations. A total of 4 data sets were compared to literature values using the regression technique described in this document.

\section{INPUT DATA}

1) The input data for $a w=f([\mathrm{NaOH}])$ is published data originated from RPP-RPT-47795, "Water Activity Data Assessment to be Used in Hanford Waste Solubility Calculations," which is a compilation of water activity data for electrolytes in aqueous solutions with corresponding references. The data set is found in Appendix A, NaOH Datasets, part $\mathrm{J}$ of RPP-RPT-47795. For our work, data referenced as originating from the International Critical Tables of Numerical Data Physics, Chemistry and Technology, Vol. III was used as it provided a wide range of water activity data with adequate accuracy for translation into a mathematical function. The data is listed in Table 1. 
Title: Multiple Regressions for Water Activity Calculations

\section{Engineer/Analyst: Jacob McCoskey}

Checker: Richard Wyrwas

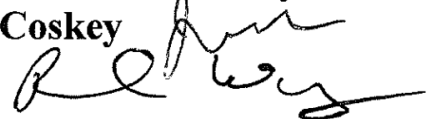

Page 6 of 20

Date: $8 / 29 / 13$

Date: $8-29-13$

Table 1. Water Activity Literature Data, International Critical tables, 1928

\begin{tabular}{ccc}
\hline $\begin{array}{c}\mathbf{N a O H} \text { Molality } \\
\mathbf{m o l} / \mathbf{k g}\end{array}$ & $\mathbf{a}_{\mathbf{w}}$ at $\mathbf{2 0}{ }^{\circ} \mathbf{C}$ & $\mathbf{a}_{\mathbf{w}} \mathbf{a t} \mathbf{6 0}{ }^{\circ} \mathbf{C}$ \\
\hline 0 & 1 & 1 \\
1.25009 & 0.963567 & 0.960123 \\
2.50018 & 0.912253 & 0.916633 \\
5.00036 & 0.79252 & 0.806236 \\
7.50054 & 0.644278 & 0.675766 \\
10.0007 & 0.496037 & 0.541951 \\
12.5009 & 0.359199 & 0.418172 \\
15.0011 & 0.250869 & 0.314465 \\
17.5013 & 0.171047 & 0.230831 \\
20.0014 & 0.114032 & 0.163923 \\
22.5016 & 0.074121 & 0.117088 \\
25.0018 & 0.051314 & 0.083634 \\
30.0022 & & 0.042152 \\
35.0025 & & 0.020072 \\
40.0029 & & 0.010036 \\
\hline
\end{tabular}

2) The input data for each of the four regressions is outlined in Table 2. Each data set includes the mean measured water activity and associated standard deviation of the ten sodium hydroxide solutions. It also includes the actual water activity calculated using $a w=f([\mathrm{NaOH}])$ for each of the ten sodium hydroxide solutions at the given temperature. 
LAB-RPT-13-00006

Appendix A

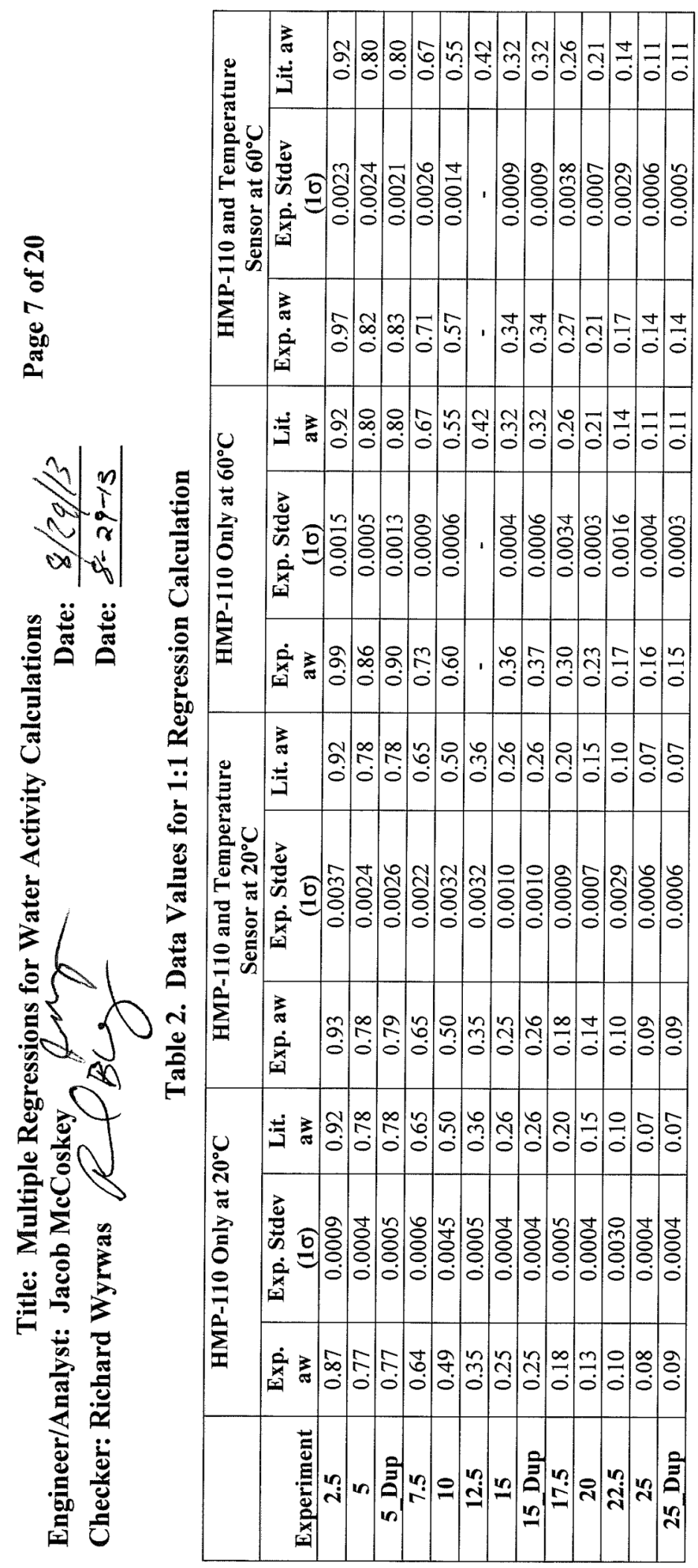


LAB-RPT-13-00006

Appendix A

Title: Multiple Regressions for Water Activity Calculations Engineer/Analyst: Jacob McCoskey

Checker: Richard Wyrwas

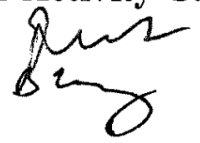

Page 8 of 20
Date: $\frac{g / 2 q / 3}{g-29-13}$
Date:

\section{METHOD OF ANALYSIS}

The sigmoid regression and linear regression was performed using a macro that is included in the IGOR Pro Version 6.21 copyrighted by WaveMetrics, Inc.

1) The sigmoid regression is menu driven and is performed using the following steps.

1. Open the IGOR program.

2. Load all data arrays in Table 2 as waves into an IGOR table.

3. Pull up the "Curve Fitting" pop-up window by accessing the Curve Fitting... option of the Analysis drop down menu.

4. Select the Function and Data tab of the pop up window.

5. Select sigmoid under the "Function" drop down menu of the Function and Data tab.

6. Select the measured data wave for the experiment of interest in the "Y Data" drop down menu of the Function and Data tab.

7. Select the literature data wave for the experiment of interest in the "X Data" drop down menu of the Function and Data tab.

8. Press the "Do It" button of the "Curve Fitting" pop-up window.

The result of the sigmoid regression is printed in the "Command Window." Several values are reported in the results, but the values of interest are chi squared, base, max, xhalf, and rate. The values are labeled in the IGOR results of the "Command Window" as "V_chisq", "base", "max", "xhalf", and "rate", respectively.

2) The linear regression is menu driven and is performed using the following steps.

1. Open the IGOR program.

2. Load all data arrays in Table 2 as waves into an IGOR table.

3. Pull up the "Curve Fitting" pop-up window by accessing the Curve Fitting... option of the Analysis drop down menu.

4. Select the Function and Data tab of the pop up window.

5. Select line under the "Function" drop down menu of the Function and Data tab

6. Select the measured data wave for the experiment of interest in the "Y Data" drop down menu of the Function and Data tab.

7. Select the literature data wave for the experiment of interest in the "X Data" drop down menu of the Function and Data tab.

8. Select the Data Options tab of the pop up window.

9. Select the data wave containing the standard deviation of the measured data in the "Weighting" drop down menu.

10. Ensure the "Standard Dev." option is selected in the Wave Contains box of the "Weighting" drop down menu box. 
LAB-RPT-13-00006

Appendix A

Title: Multiple Regressions for Water Activity Calculations

Engineer/Analyst: Jacob McCoskey

Checker: Richard Wyrwas

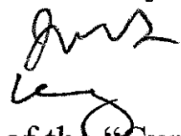

Page 9 of 20

Date: $y / 2 q / 13$

Date: $8-29-13$

11. Press the "Do It" button of the Curve Fitting" pop-up window.

The result of the linear regression is printed in the "Command Window." Several values are reported in the results, but the values of interest are the coefficient of determination $\left(\mathrm{R}^{2}\right)$, the regression intercept (a) and the regression slope (b). The values are labeled in the IGOR results of the "Command Window" as "V_r2", "a" and "b", respectively.

\section{COMPUTER SOFTWARE}

IGOR Pro, version 6.02, was used to conduct these calculations and is registered in HISI under HISI \# 2910. It is graded as N/A software and was approved for use on 8/06/2013.

\section{RESULTS}

The results of the sigmoid fit to the literature $\mathrm{NaOH}$ water activity data is displayed in Table 3 .

Table 3. Results of Sigmoid Regression of Literature NaOH Solution Water Activity Data

\begin{tabular}{ccc}
\hline Constant & Value at $20^{\circ} \mathbf{C}$ & Value at $60^{\circ} \mathbf{C}$ \\
\hline Base & $1.1825 \pm 0.0204$ & $1.2472 \pm 0.014$ \\
Max & $-1.1656 \pm 0.0263$ & $-1.2391 \pm 0.0156$ \\
Xhalf & $8.281 \pm 0.178$ & $8.4124 \pm 0.153$ \\
Rate & $4.8474 \pm 0.164$ & $5.9522 \pm 0.0962$ \\
\hline & & \\
\hline Quality of Fit & & $1.61845 \times 10^{-4}$ \\
\hline Chi Squared & $5.51378 \times 10^{-5}$ & \\
\hline
\end{tabular}

Table 4 contains the results of the 1:1 regressions for each of the four experiments.

Table 4. Experiment Results of 1:1 Regressions

\begin{tabular}{|l|c|c|c|}
\hline Experiment & $\mathbf{a}$ & $\mathbf{b}$ & $\mathbf{R}^{2}$ \\
\hline HMP-110 Only at $20^{\circ} \mathrm{C}$ & $0.0012 \pm 0.00022$ & $0.98 \pm 0.00050$ & 1.02 \\
\hline HMP-110 and Temperature Sensor at $20^{\circ} \mathrm{C}$ & $0.011 \pm 0.00043$ & $0.96 \pm 0.0018$ & 0.93 \\
\hline HMP-110 Only at $60^{\circ} \mathrm{C}$ & $0.030 \pm 0.00024$ & $1.04 \pm 0.00065$ & 0.96 \\
\hline HMP-110 and Temperature Sensor at $60^{\circ} \mathrm{C}$ & $0.023 \pm 0.00045$ & $1.00 \pm 0.0015$ & 0.96 \\
\hline
\end{tabular}

\section{CONCLUSIONS}


LAB-RPT-13-00006

Appendix A

Title: Multiple Regressions for Water Activity Calculations

Engineer/Analyst: Jacob McCoskey

Page 10 of 20
Date: $\frac{y / 29 / 13}{y-2 q-13}$

IOGR Pro successfully fitted a sigmoid function to the water activity of various $\mathrm{NaOH}$ solutions at both $20^{\circ} \mathrm{C}$ and $60^{\circ} \mathrm{C}$. The results of the IGOR fit were compared to the results of an OriginPro fit and the outputs from each of the programs were nearly identical.

IGOR accurately calculated the slope and intercept of the 1:1 regression of the four experiments. Also, the output was compared to a similar regression completed using Origin Pro and the data outputs were nearly identical. Also, the coefficient of determination was reported. The determined values are of expected magnitude 
LAB-RPT-13-00006

Appendix A

Title: Multiple Regressions for Water Activity Calculations

Engineer/Analyst: Jacob McCoskey

Checker: Richard Wyrwas $O C O$ C

Page 11 of 20

Date: $\frac{4 / 21 / 13}{8-29-13}$

7. REFERENCES

IGOR Pro Version 6.2, WaveMetrics, Inc., I ake Oswego, Oregon, 2010

LAB-RPT-13-00006, 2013, Instrument Qualification of Custom Fabricated Water Activity Meter for Hot Cell Use, Washington River Protection Solutions LLC, Richland, Washington.

RPP-RPT-47795 Rev. 3, 2011, Water Activity Data Assessment to be used in Hanford Waste

Solubility Calculations, Washington River Protection Solutions LLC, Richland, Washington. 


\section{APPENDIX 1. IGOR OUTPUT OF SIGMOID REGRESSIONS}

\section{Water Activity of $\mathrm{NaOH}$ Solutions at $20^{\circ} \mathrm{C}$}

CurveFit/NTHR=0 Sigmoid aw_20_NaOH[0,11] $/ \mathrm{X}=\mathrm{NaNO} \_\mathrm{NaOH} / \mathrm{D} / \mathrm{F}=\{0.950000,4\}$

Fit converged properly

Curve fit with data subrange:

$$
\text { aw_20_NaOH[0,11] }
$$

fit_aw_20_NaOH=W_coef[0] + W_coef[1]/(1+exp $\left.\left(-\left(x-W \_c o e f[2]\right) / W \_c o e f[3]\right)\right)$

W_coef $=\{1.1825,-1.1 \overline{6} 56,8.281,4.8 \overline{4} 74\}$

$\mathrm{V}$-chisq $=5.51378 \mathrm{e}-005 ; \mathrm{V} \_$npnts $=12 ; \mathrm{V} \_$numNaNs $=0 ; \mathrm{V} \_$numINFs $=0$;

V_startRow $=0 ; \mathrm{V}$ endRow $=11$;

W_sigma $=\{0.008 \overline{8} 6,0.0114,0.0771,0.0711\}$

Fit coefficient confidence intervals at $95.00 \%$ confidence level:

W_ParamConfidenceInterval $=\{0.0204,0.0263,0.178,0.164,0.95\}$

Coefficient values $\pm 95 \%$ Confidence Interval

$$
\begin{array}{ll}
\text { base } & =1.1825 \pm 0.0204 \\
\max & =-1.1656 \pm 0.0263 \\
\text { xhalf } & =8.281 \pm 0.178 \\
\text { rate } & =4.8474 \pm 0.164
\end{array}
$$

\section{Water Activity of $\mathrm{NaOH}$ Solutions at $60^{\circ} \mathrm{C}$}

CurveFit/NTHR=0 Sigmoid aw_60_NaOH $/ \mathrm{X}=\mathrm{NaNO} 3 \_\mathrm{NaOH} / \mathrm{D}$

Fit converged properly

fit_aw_60_NaOH=W_coef[0] $+\mathrm{W} \_$coef[1] $/\left(1+\exp \left(-\left(\mathrm{x}-\mathrm{W} \_\right.\right.\right.$coef[2] $) / \mathrm{W} \_$coef[3] $\left.)\right)$

W_coef $=\{1.2472,-1.2391,8.4124,5 . \overline{9} 522\}$

$\mathrm{V} \_$chisq $=0.000161845 ; \mathrm{V} \_$npnts $=15 ; \mathrm{V} \_$numNaNs $=0 ; \mathrm{V} \_$numINFs $=0$;

V_startRow $=0 ; \mathrm{V} \_$endRow $=14$;

W_sigma $=\{0.014,0.0156,0.153,0.0962\}$

Coefficient values \pm one standard deviation

$$
\begin{array}{ll}
\text { base } & =1.2472 \pm 0.014 \\
\max & =-1.2391 \pm 0.0156 \\
\text { xhalf } & =8.4124 \pm 0.153 \\
\text { rate } & =5.9522 \pm 0.0962
\end{array}
$$


LAB-RPT-13-00006

Appendix A

Title: Multiple Regressions for Water Activity Calculations

Engineer/Analyst: Jacob McCoskey

Checker: Richard Wyrwas $R Q u$

Date: $8 / 29 / 13$

Date: $8-29-13$

\section{APPENDIX 2. IGOR OUTPUT OF LINEAT REGRESSIONS}

\section{HMP-110 Only at $20^{\circ} \mathrm{C}$}

CurveFit/NTHR $=0$ line Water_Activity_Avg_Vapor_/X=Modeled_Water_Activity

$/ \mathrm{W}=$ Water_Activity_Std_1sig_Vapor_/I $=1 / \mathrm{D}$

fit_Water_Activity_Avg_Vapor_ $=\bar{W}_{-}$coef $[0]+W \_c o e f[1]^{*} \mathrm{x}$

W_coef $=\{0.00123 \overline{44}, 0.97585\}$

$\mathrm{V}$ _chisq $=8333.85 ; \mathrm{V} \_$npnts $=13 ; \mathrm{V} \_$numNaNs $=0 ; \mathrm{V}$ numINFs $=0$;

V_startRow $=0 ; \mathrm{V} \_$endRow $=12 ; \mathrm{V} \_\mathrm{q}=0 ; \mathrm{V} \_\mathrm{Rab}=-0.781291$;

$\mathrm{V} \_\mathrm{Pr}=0.933607 ; \overline{\mathrm{V}} \mathrm{r} 2=1.01824$;

W_sigma $=\{0.000219,0.000502\}$

Coefficient values \pm one standard deviation

$$
\begin{array}{ll}
\mathrm{a} & =0.0012344 \pm 0.000219 \\
\mathrm{~b} & =0.97585 \pm 0.000502
\end{array}
$$

HMP-110 and Temperature Sensor at $20^{\circ} \mathrm{C}$

CurveFit/NTHR $=0$ line Water_Activity_Avg_Solution_/X=Modeled_Water_Activity

$/ \mathrm{W}=$ Water_Activity_Std_1sig_Soluti /I=1/D

fit_Water_Activity_Avg_Solutio $=$ W_coef $[0]+W \_$coef $[1]^{*} \mathrm{x}$

W_coef $=\{0.0113,0.96245\}$

$\mathrm{V}$ _chisq $=2354.56 ; \mathrm{V} \_$npnts $=13 ; \mathrm{V} \_$numNaNs $=0 ; \mathrm{V} \_$numINFs $=0$;

$\mathrm{V}$ _startRow $=0 ; \mathrm{V}$ endRow $=12 ; \mathrm{V} \_\mathrm{q}=0 ; \mathrm{V} \_\mathrm{Rab}=-0.732706$;

V_Pr $=0.903335 ; \bar{V}_{-}$r2 $=0.933553$;

W_sigma $=\{0.0004 \overline{2} 9,0.00184\}$

Coefficient values \pm one standard deviation

$$
\begin{array}{ll}
\mathrm{a} & =0.0113 \pm 0.000429 \\
\mathrm{~b} & =0.96245 \pm 0.00184
\end{array}
$$

\section{HMP-110 Only at $60^{\circ} \mathrm{C}$}

CurveFit/NTHR $=0 /$ TBOX $=769$ line Mean_HMP110/X=Actual_Water_Activity

$/ \mathrm{W}={ }^{\prime} 1 \mathrm{~s}$ StDev HMP110' $/ \mathrm{I}=1 / \mathrm{D}$

fit_Mean_HMP110 $=$ W_coef[0]+W_coef $[1]{ }^{*} \mathrm{x}$

W_coef $=\{0.029802,1.0 \overline{385}\}$

$\mathrm{V} \_$chisq $=6710.35 ; \mathrm{V} \_$npnts $=12 ; \mathrm{V} \_$numNaNs $=0 ; \mathrm{V} \_$numINFs $=0$;

V_startRow $=0 ; \mathrm{V}$ endRow $=12 ; \mathrm{V} \_\mathrm{q}=0 ; \mathrm{V} \_\mathrm{Rab}=-0.789862$;

V_Pr $=0.860334 ; \bar{V} \_r 2=0.963943$;

W_sigma $=\{0.0002 \overline{3} 8,0.000647\}$

Coefficient values \pm one standard deviation

$$
\begin{array}{ll}
\mathrm{a} & =0.029802 \pm 0.000238 \\
\mathrm{~b} & =1.0385 \pm 0.000647
\end{array}
$$


Title: Multiple Regressions for Water Activity Calculations Engineer/Analyst: Jacob McCoskey Checker: Richard Wyrwas
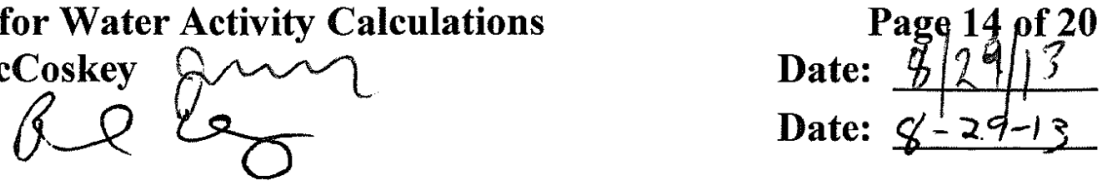

HMP-110 and Temperature Sensor at $60^{\circ} \mathrm{C}$

CurveFit/NTHR=0/TBOX=769 line 'Mean_HMP\&Temp' $/ \mathrm{X}=$ Actual_Water_Activity

$/ \mathrm{W}=$ '1s StDev HMP\&Temp' $/ \mathrm{I}=1 / \mathrm{D}$

'fit_Mean_HMP\&Temp' $=$ W_coef $[0]+W \_$coef $[1]^{*} \mathrm{x}$

W_coef $=\{0.023432,0.99815\}$

$\mathrm{V}$ _chisq $=1647.84 ; \mathrm{V} \_$npnts $=12 ; \mathrm{V}$ numNaNs $=0 ; \mathrm{V}$ numINFs $=0$;

V_startRow $=0 ; \mathrm{V}$ endRow $=12 ; V_{-}$q $=0 ; V_{-}$Rab $=-0.779027$;

$\mathrm{V}-\mathrm{Pr}=0.911342 ; \overline{\mathrm{V}} \mathrm{r} 2=0.963254$;

W_sigma $=\{0.000447,0.00154\}$

Coefficient values \pm one standard deviation
$\mathrm{a} \quad=0.023432 \pm 0.000447$
b $\quad=0.99815 \pm 0.00154$ 
LAB-RPT-13-00006

Appendix A

Title: Multiple Regressions for Water Activity Calculations

Page 15 of 20

Engineer/Analyst: Jacob McCoskey

Checker: Richard Wyrwas

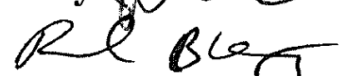

Date: $8 / 29 / 13$

Date: $8+29-13$

APPENDIX 3. RESULTS OF SIGMOID REGRESSION CHECK USING ORIGIN PRO VERSION 9.00

Figure A-1. Origin Pro check of sigmoid regression of $\mathrm{NaOH}$ water activity at $20^{\circ} \mathrm{C}$

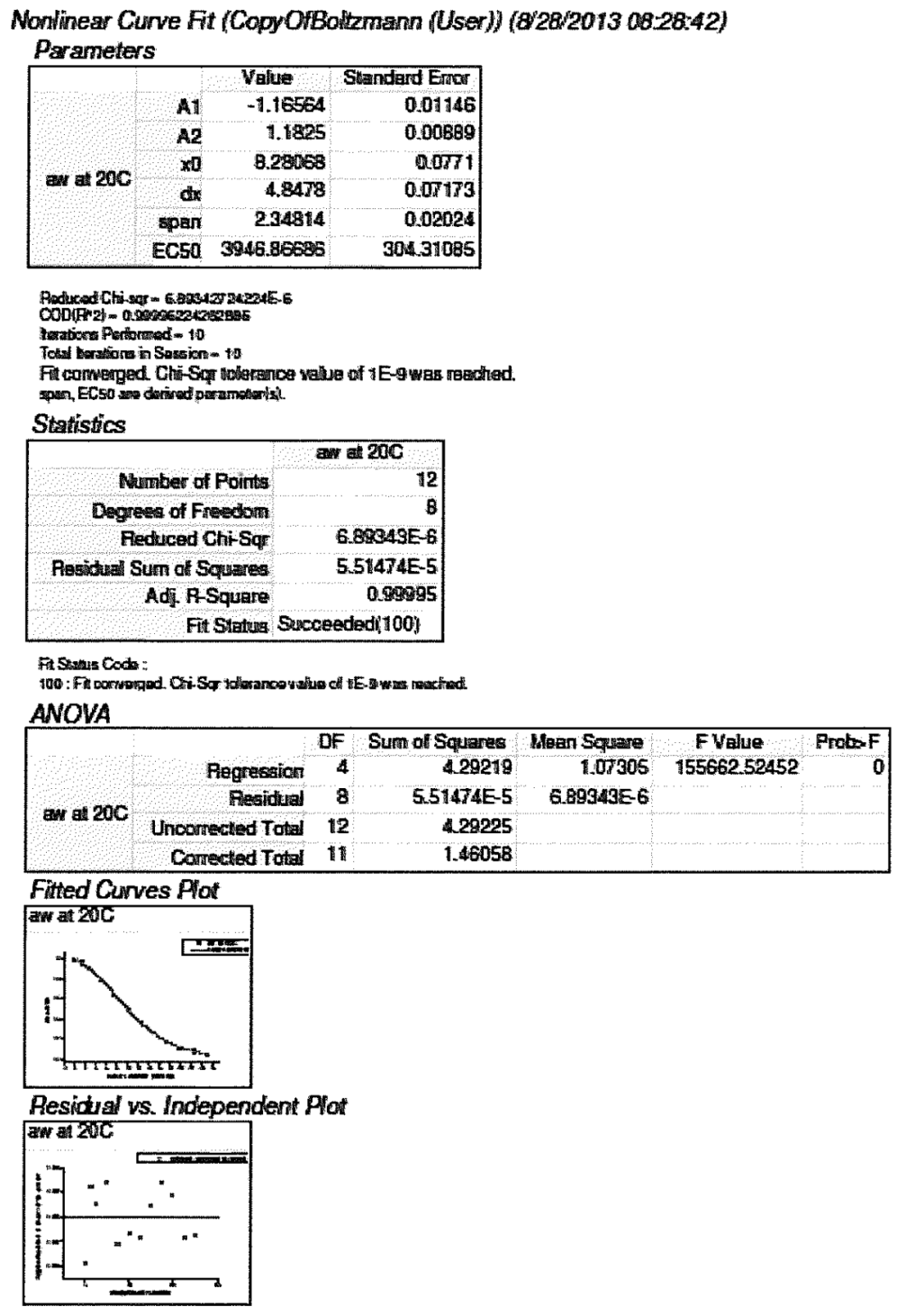


LAB-RPT-13-00006

Appendix A

Title: Multiple Regressions for Water Activity Calculations

Engineer/Analyst: Jacob McCoskey

Checker: Richard Wyrwas $P$ P

Page 16 of 20

Date: $\frac{y / 22 / 13}{8-29-13}$

Date: $8-29-13$

Figure A-2. Origin Pro check of sigmoid regression of $\mathrm{NaOH}$ water activity at $60{ }^{\circ} \mathrm{C}$

Nonlinear Curve Fit (CopyOHBolzmann (User)) (8'28/2013 08:40:19)

\begin{tabular}{|c|c|c|c|}
\hline \multirow[b]{3}{*}{ ar at $60 \mathrm{C}$} & \multicolumn{2}{|c|}{ Deplindep } & Dafa \\
\hline & $x$ Indep & \multirow{2}{*}{\multicolumn{2}{|c|}{ [Book5BSheet 1 IA ' $\mathrm{KaO}$}} \\
\hline & Dep & BBook: & \\
\hline \multicolumn{4}{|c|}{ Parameters } \\
\hline \multirow{7}{*}{ an at $60 \mathrm{C}$} & & Value & Standard Enror \\
\hline & A1 & -1.23929 & 0.01566 \\
\hline & A2 & 1.24738 & 0.01399 \\
\hline & $x D$ & 8.41087 & 0.15278 \\
\hline & $d x$ & 5.95329 & 0.09673 \\
\hline & span & 2.48666 & 0.02957 \\
\hline & EC50 & 4495.66115 & 686.83421 \\
\hline
\end{tabular}

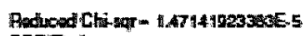

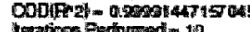

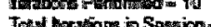

Fit converged. Chi-Sor tollatenca value of 1 E-9 was naphed.

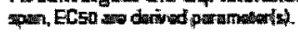

Statistics

\begin{tabular}{|c|c|c|c|c|c|c|c|}
\hline \multicolumn{8}{|c|}{ ay al 600} \\
\hline \multicolumn{2}{|c|}{ Number of Points } & & 15 & & & & \\
\hline \multicolumn{2}{|c|}{ Degrees of Freedom } & & 11 & & & & \\
\hline \multicolumn{2}{|c|}{ Reduced Chi-Sqr } & & $7142 E-5$ & & & & \\
\hline \multicolumn{2}{|c|}{ Pesidual Sum of Squares } & & $31856 E-4$ & & & & \\
\hline \multicolumn{2}{|c|}{ Adf R Square } & & 0.99989 & & & & \\
\hline \multicolumn{4}{|c|}{ Fit Status Succeeded(100) } & & & & \\
\hline \multicolumn{8}{|c|}{ 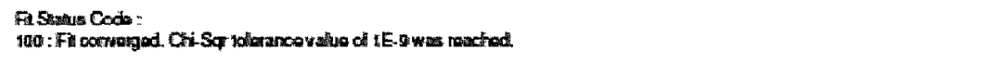 } \\
\hline \multicolumn{8}{|c|}{ ANOWA } \\
\hline \multirow{5}{*}{ an at $60 \mathrm{C}$} & & DF & Sum of & Squares & Mean Squpare & FVolne & ProbsF \\
\hline & Regression & 4 & & 4.59917 & 1.13479 & 77122.34100 & 0 \\
\hline & Residual & 11 & & S1B56E-4 & $1.47142 E-5$ & & \\
\hline & Uncarnected Total & 15 & & 4.59939 & & & \\
\hline & Conected Total & 14 & & 1.89242 & & & \\
\hline
\end{tabular}

Fithed Curves Plot

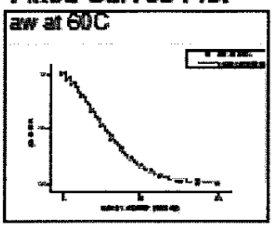

Residual vs. Independent Plot

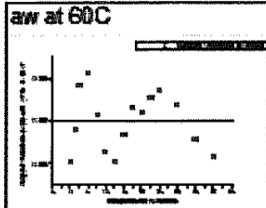


LAB-RPT-13-00006

Appendix A

Title: Multiple Regressions for Water Activity Calculations

Engineer/Analyst: Jacob McCoskey

Page 17 of 20

Date: $8 / 2 9 \longdiv { 1 3 }$

Date: $8-29-13$

\section{APPENDIX 4. RESULTS LINEAR REGRESSION CHECK USING ORIGIN PRO}

VERSION 9.00

Figure A-3. HMP-110 Only at $20^{\circ} \mathrm{C}$

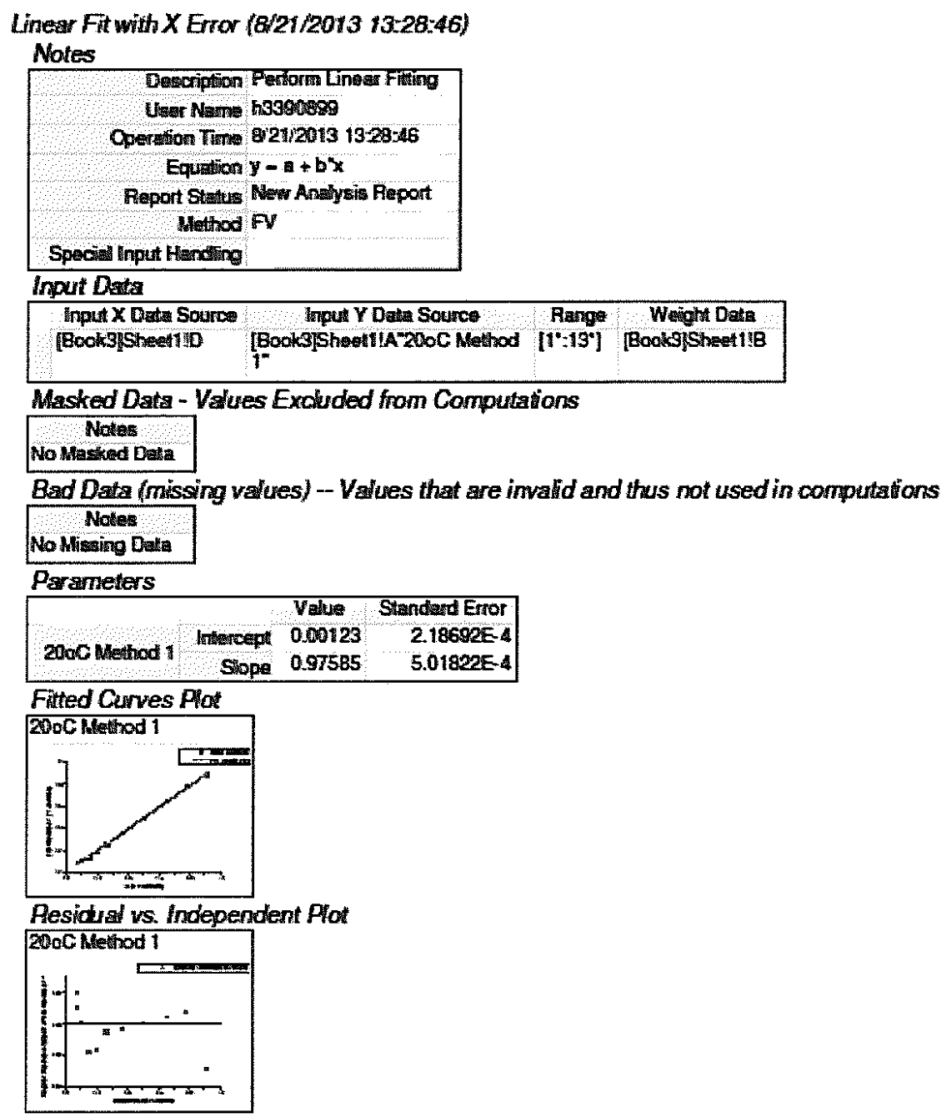


LAB-RPT-13-00006

Appendix A

Title: Multiple Regressions for Water Activity Calculations Engineer/Analyst: Jacob McCoskey

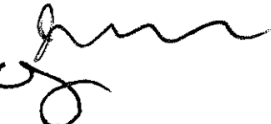

Page 18 of 20

Checker: Richard Wyrwas

Date: $\$ 29 / 13$

Date: $8-29-13$

Figure A-4. HMP-110 and Temperature Sensor at $20^{\circ} \mathrm{C}$

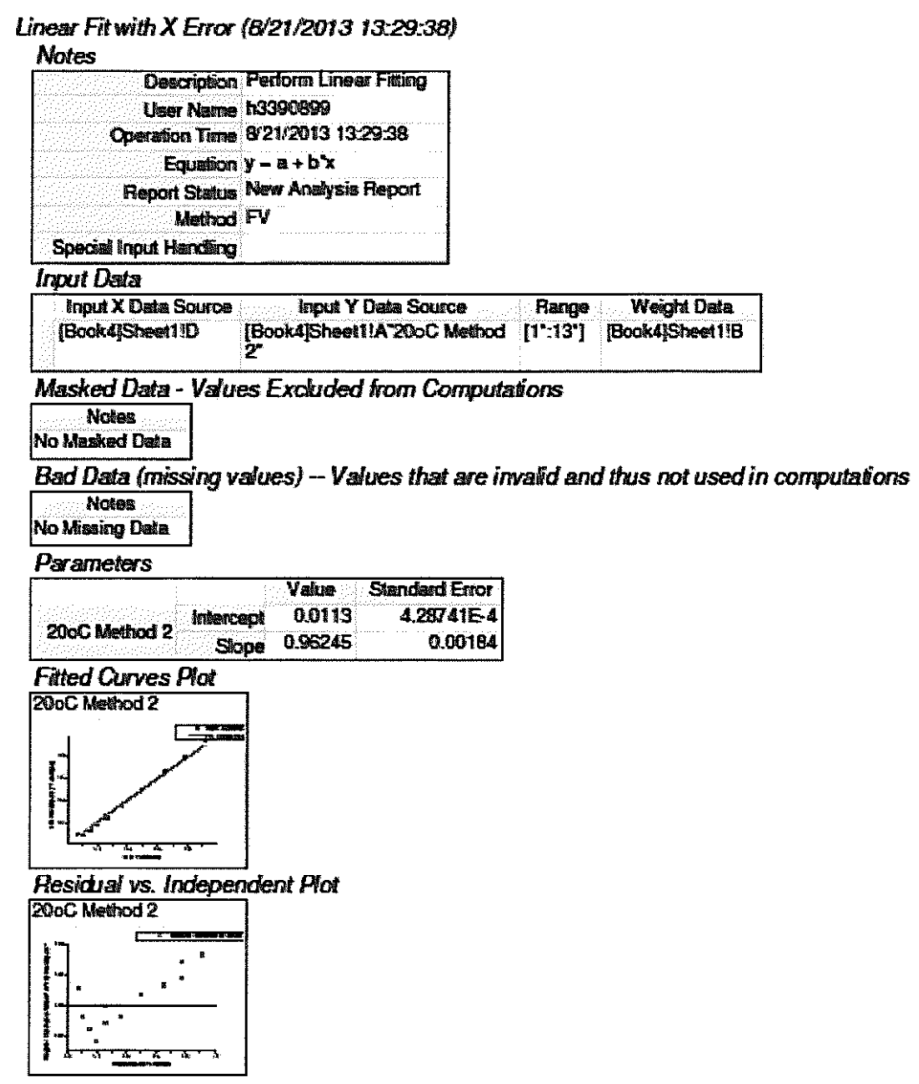


LAB-RPT-13-00006

Appendix A

Title: Multiple Regressions for Water Activity Calculations Engineer/Analyst: Jacob McCoskey

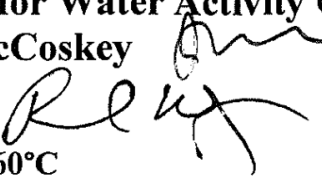

Page, 19 of 20

Checker: Richard Wyrwas

Figure A-5. HMP-110 Only at $60^{\circ} \mathrm{C}$

Date: $\frac{8 / 29 / 1}{8-29-13}$

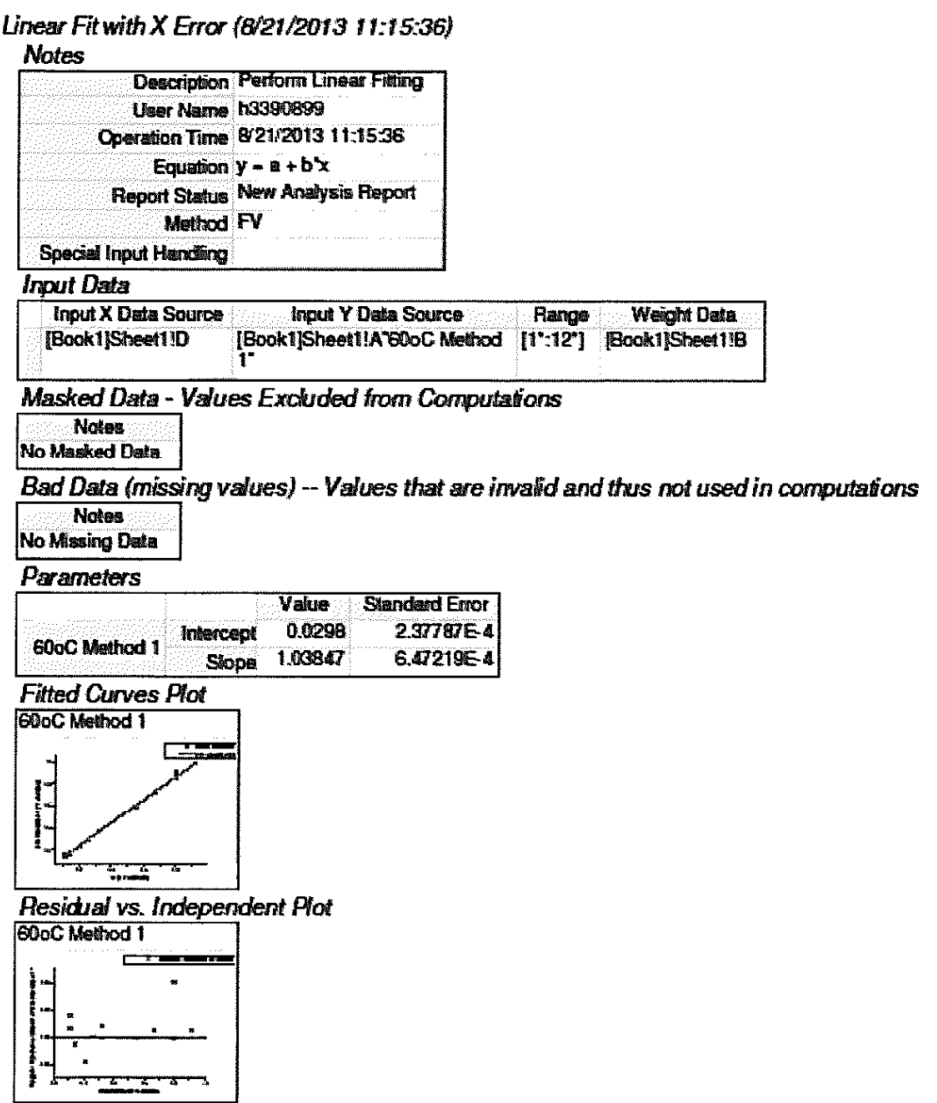


LAB-RPT-13-00006

Appendix A

Title: Multiple Regressions for Water Activity Calculations Engineer/Analyst: Jacob McCoskey

Checker: Richard Wyrwas
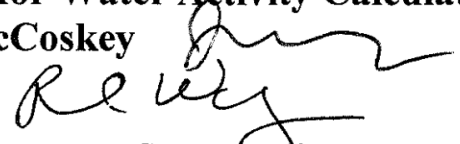

Page 20 of 20

Date: $\$ / 2 a / 13$

Date: $8 \cdot 29-13$

Figure A-6. HMP-110 and Temperature Sensor at $60^{\circ} \mathrm{C}$

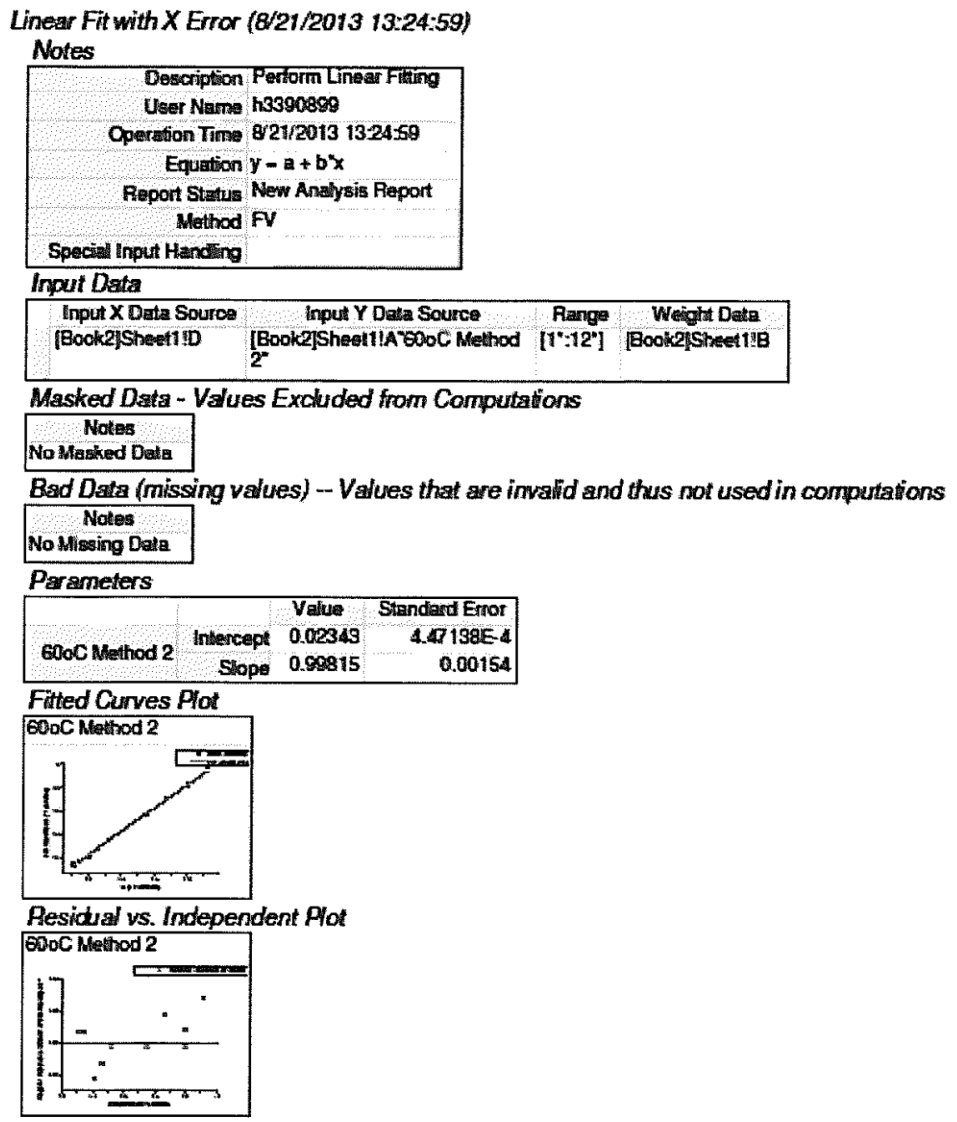




\section{Electronically Approved by:}

UserName: McCoskey, Jacob (h3952850)

Title:

Date: Thursday, 09 January 2014, 07:54 AM Pacific Time

Meaning: Approved by the author or delegate

UserName: Cooke, Gary (h0410221)

Title: APD Chemist

Date: Friday, 10 January 2014, 12:30 PM Pacific Time

Meaning: Approved by the customer or delegate

=ニ=ニ=ニ=ニ=ニ=ニ=ニ=ニ=ニ=ニ=ニ=ニ=ニ=ニ=ニ=ニ=ニ=ニ=ニ=ニ=ニ=ニ=

UserName: Greenough, Keith (h0068375)

Title: Laboratory Facilities

Date: Tuesday, 14 January 2014, 09:17 AM Pacific Time

Meaning: Approved by the Facility Manager or delegate

UserName: Cooke, Gary (h0410221)

Title: APD Chemist

Date: Tuesday, 14 January 2014, 05:01 PM Pacific Time

Meaning: Approved by the Group Manager or delegate 